\title{
UMASS/AMHERST
}

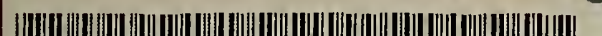

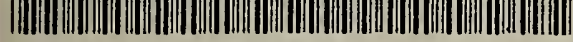

312066005846604 



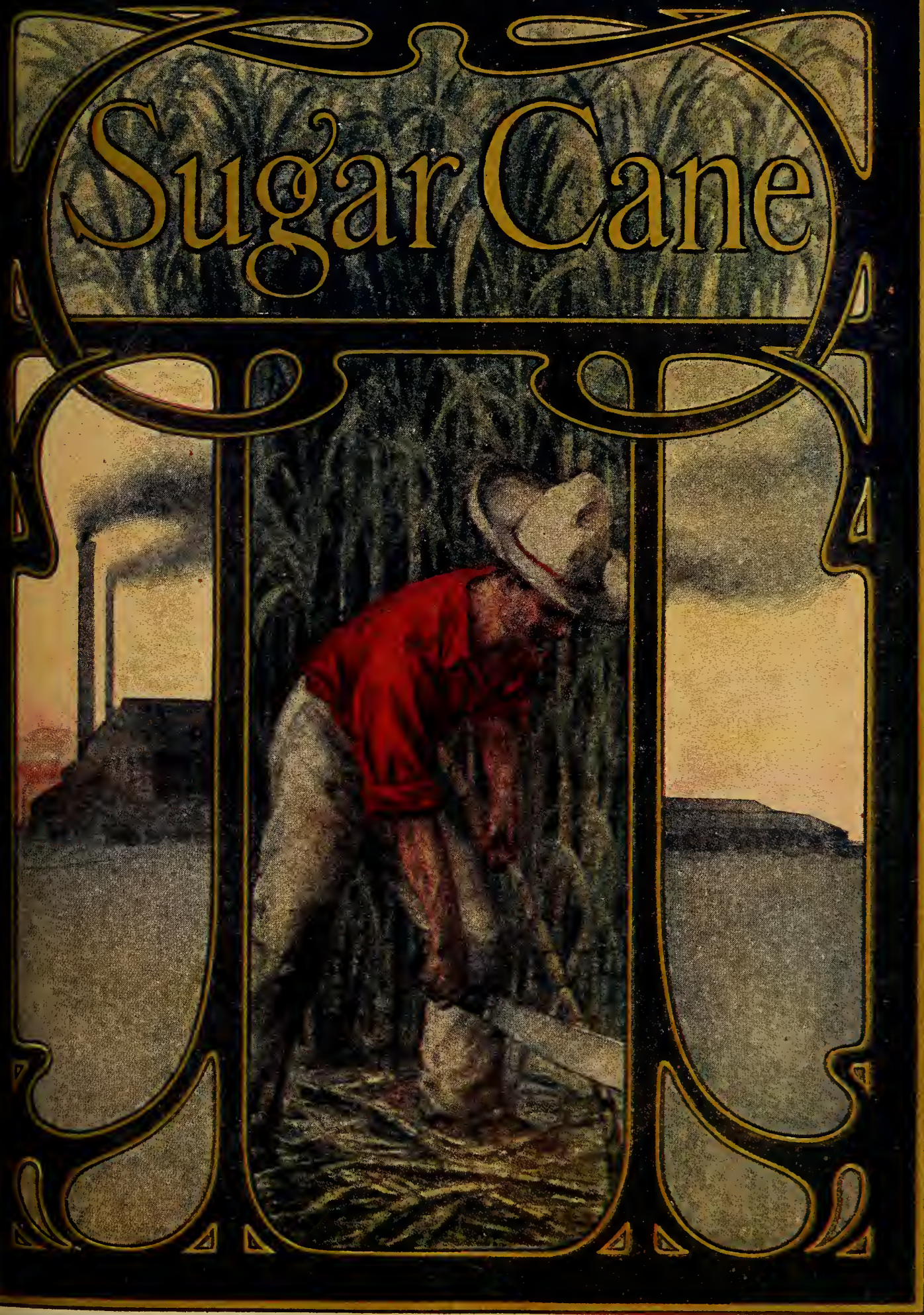





\section{Sugar Cane Culture.}

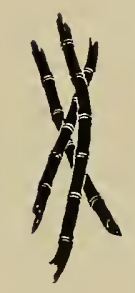

Published by

GERMAN KALI WORKS,

93 NASSAU STREET,

NEW YORK. 


\section{NOTICE.}

This pamphlet will be sent free to applicants. Other publications for free distribution are :

"FERTILIZING SUGAR CANE,"

(English and Spanish.)

"FERTILIZING OF SUGAR CANE IN THE HAWAIIAN ISLANDS," (English and Spanish.)

"FERTILIZING TOBACCO,"

(English and Spanish.)

"TROPICAL PLANTING,"

(English and Spanish.)

"PLANT FOOD,"

"TRUCK FARMING."

Address,

GERMAN KALI WORKS,

93 Nassau Street, New York, U. S. A. 


\section{INDEX.}

PAGE

History of the Sugar Cane............... 6

Botany........................ 12

Anatomy.......................... ${ }_{7}$

Climate for Cane.$\ldots \ldots \ldots \ldots \ldots \ldots \ldots \ldots \ldots \ldots$. 19

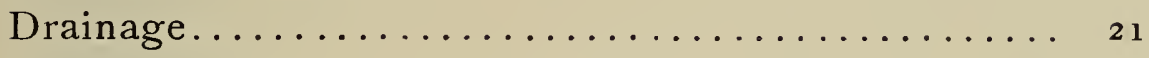

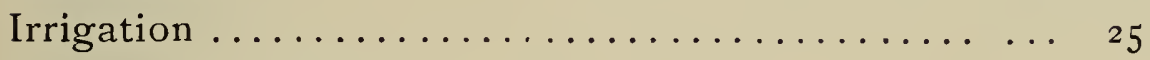

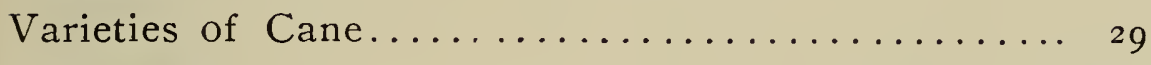

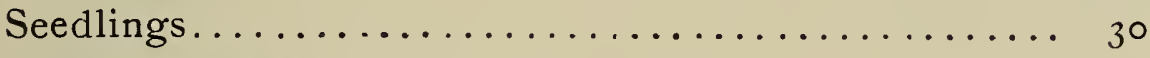

Soils for Sugar Culture................. 33

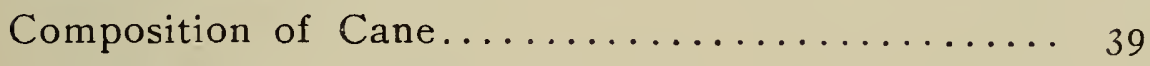

Fertilizing Requirements of Cane . ......... 45

Stable Manures and Green Manuring................... 50

Fertilizer Requirements of Cane Soils.......... 52

Quantity of Fertilizers per Acre, and how to apply

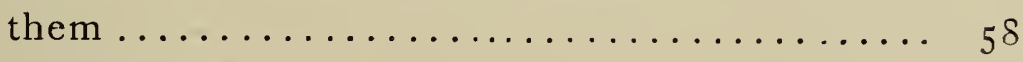

Value of Fertilizers............... 6 r

Tables giving composition of fertilizer materials and

farm manures.................. 6768 



\section{PREFACE.}

$A$ LL thoughtful sugar planters realize the absolute A necessity of intelligent and progressive methods in growing the cane in order to secure profit. The languishing of this important industry has been caused by antiquated, expensive, unscientific methods of cultivating, planting and fertilizing the sugar crop. These points are brought out clearly by comparison with the sugar beet, a plant naturally containing but little sugar, and the cane plant, which is a natural and far superior sugar producer.

By persistent effort and scientific methods, the sugar beet has been wonderfully developed, so that five-eighths of the world's supply of sugar is derived from it. While this development of the beet has been in progress, the cane, in many countries, has received little or no attention. Prices of sugar have declined, but the cost of producing it, in the old way, has remained the same. The natural result is, that, in many sections, the sugar planter did not realize the real conditions confronting him until he found his profits gone, and his estates encumbered with debt. Fortunately some countries and some planters were more wise,- - have been modern, progressive and abreast with the advance thought of the age; these are to-day leading the world in the production of sugar.

It is for the purpose of helping all sugar planters, who wish to better their condition, that this little pamphlet of modern practices in cane culture is issued. 


\section{HISTORY OF THE SUGAR CANE.}

$\mathrm{I}^{\mathrm{T}}$ is claimed, and probably true, that sugar cane was first cultivated in China, and sugar manufactured from it over a thousand years before its introduction into Europe. Undoubtedly the Chinese were early manufacturers of sugar, and claim that they were the first, but on this point there is considerable doubt. They themselves candidly confess that it came to them from the East. In their most ancient works no allusion to it has been found. In the second century B. C. its authors speak of it, and in the fourth century A. D. it is described in a work which calls it the "Kan-che," (Kan-sweet and che-bamboo). "It grows in Cochin China. It is many inches in diameter and resembles bamboo. The stalk broken into fragments is eatable and very sweet. The juice which is drawn from it is dried in the sun. After some days it becomes sugar." In the year $286 \mathrm{~A}$. D. the Kingdom of Turran in India sent sugar as a tribute to China.

De Condolle says, "it has been demonstrated by a crowd of historical witnesses, that sugar cane was first cultivated in meridional Asia, whence it has spread into Africa and later into America."

Karl Ritter stated, that all the varieties of cane known in a wild state and belonging to the genus "saccharum" grew in India except one which was in Egypt. 
Linguistic and historical facts support the claim of Asiatic origin. All European languages of Aryan origin have names for sugar, derived from the Sanskrit "Sakkara or Sarkara," but those not of Aryan origin have a great variety of names for both "sugar" and "cane." This similarity of names on the one hand, and the diversity on the other, support the presumption of the great antiquity of its culture in Asia, where botanical indications presumed its origin.

Sugar cane was found growing in many of the Pacific Islands at the time they were discovered by the white man, and it was inferred that it was indigenous, but it has since been indisputably proved that it, with many other useful plants, was carried by the Maori race in all of its migrations, and that they had obtained it from India. As far as modern research has been able to ascertain, it came to China from Cochin China, and had its origin either in that country or Bengal.

The Greeks and the Romans were acquainted with the propagation of sugar cane in the West of India, as is shown by the writings of Paulus Egineta, Theophrastus, Dioscorides, Pliny, Varro, Seneca and others. Sugar was called "Indian salt," "honey from bamboo," "a honey concocted in India and Arabia," "a honey produced either by the dew of heaven or by the sweet and thick sap of the reed," "a concretion similar to our own salt, and which, when subjected to the teeth, breaks up after the manner of salt." 
Hebrew writers do not mention sugar or sugar cane, and it is inferred that the culture of cane did not exist in the East of India at the time of the "Captivity of the Jews at Babylon."

From what has been said, the deduction follows, that its seemingly trustworthy history makes India the original home or at least the first place where it had food, or commercial value, and from there spread into China, where it has been extensively cultivated for many centuries. Thence it passed to Arabia, Nubia, Ethiopia and Egypt.

The Venetians (about I500 A. D.) introduced sugar cane into Syria, Cyprus and Sicily. Dom Henri, King of Portugal, imported it into the Madeira and Canary Islands, where for 300 years, all of the sugar consumed in Europe was manufactured. It was next introduced into Southern Spain, where its culture still prevails, though within a restricted territory. At the beginning of the sixteenth century it was carried from the Canaries to Brazil. Soon after the discovery of the New World, Peter Etienza took its cultivation to the Island of St. Domingo, whence it spread over all the West India Islands and Central and South America.

In the United States it is now cultivated along the entire Gulf coast. It was introduced into Louisiana in I 757, and became, in 1795 , extensively cultivated, and has since then been the chief crop of the State. In Florida it had a checkered career from 1757 to 1825 , when it became permanently domesticated and has since been extensively grown for syrup making. 


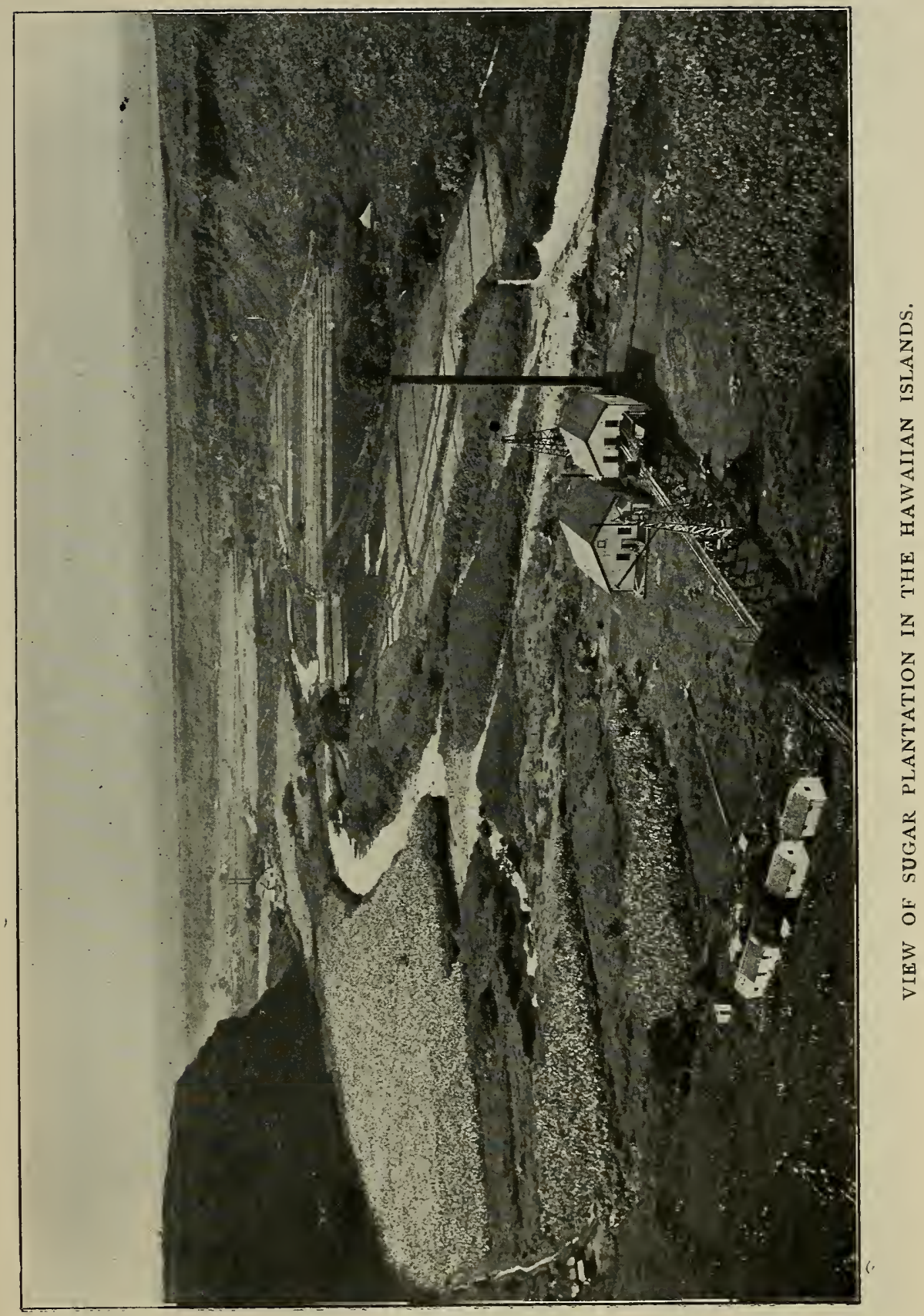




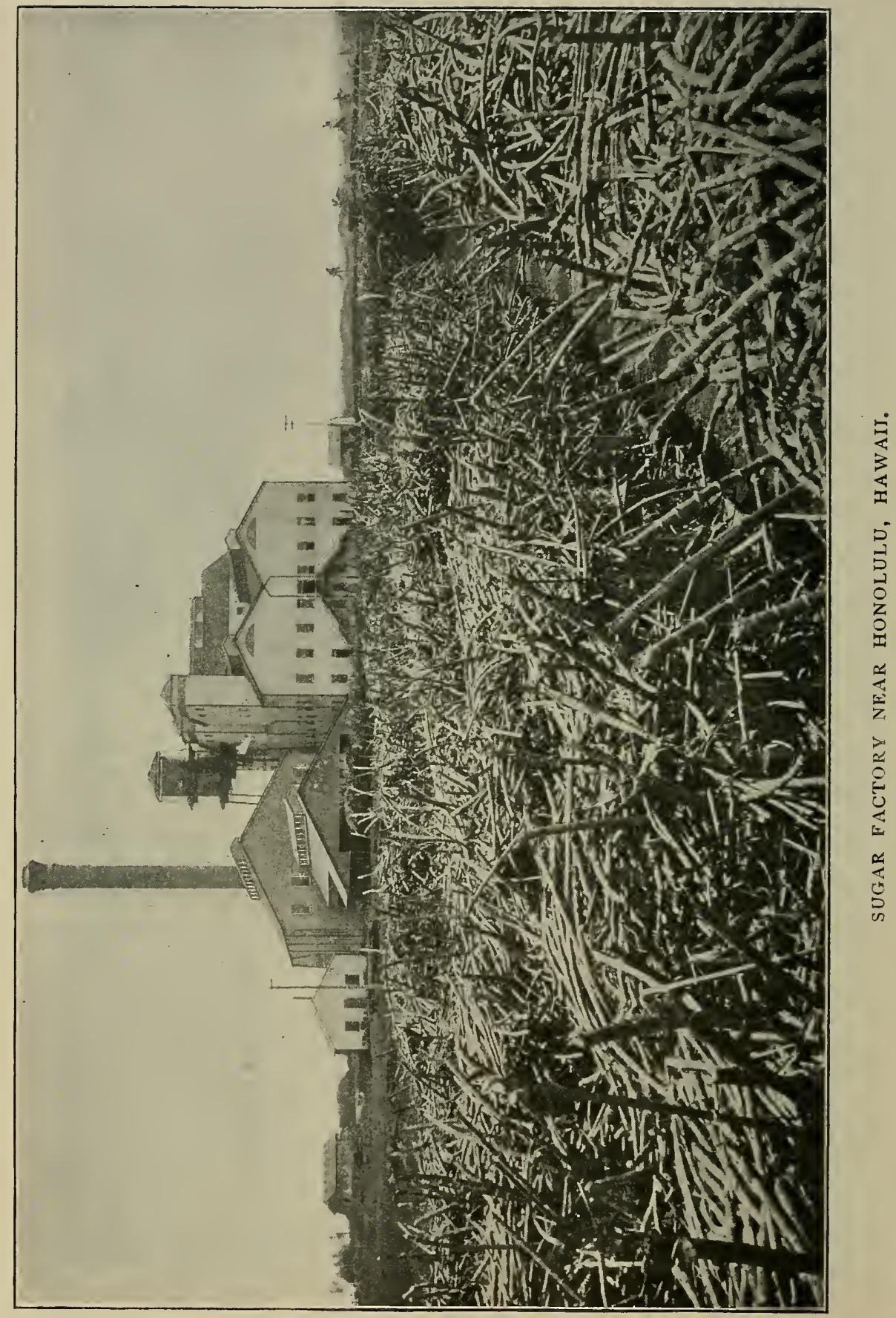


In Georgia, Mr. Thomas Spalding began its cultivation in 1805 , and soon after large estates were devoted to it and sugar houses were established. The discovery of the cotton gin and the wonderful impetus, which it gave cotton culture, caused an abandonment of cane growing by the large planters on the alluvial coast lands, but the small farmers of the interior took it up and grew it in patches and manufactured it, by the crudest machinery, into syrup for home consumption. To-day sugar cane is grown in over fifty counties of this State, and an enormous quantity of excellent syrup and some sugar is annually made. Georgia syrup finds its way to nearly every market in the United States.

In the southern parts of South Carolina, Alabama and Mississippi numerous small patches of sugar cane are cultivated and converted into syrup and sugar by the same primitive methods as in Georgia. Only Texas and Louisiana are deeply interested in the manufacture of sugar. In the former State there are twenty or more large sugar houses, and in the latter over four hundred, yielding in the aggregate annually nearly 400,000 tons of sugar. This does not include the large number of scattering patches, in each State, grown for the home manufacture of syrup for home consumption.

The manufacture of syrup upon a small scale, with horse mills and small kettles or open pans, is an enormous industry when considered in the aggregate. From Wilmington, N. C., on down the Atlantic coast and across to the Gulf, 
following its coast to the Rio Grande, is a section of country well adapted to the growth of cane.

It varies in width from 100 to 300 miles, and a traveller through it, in the growing season, is rarely out of sight of a cane patch. The methods of manufacture are extremely primitive, almost criminally wasteful, yet the syrup made is excellent in quality, and quantities of it find their way, at profitable prices, to the North and West after the home demand has been supplied.

Better methods of cultivating, fertilizing and harvesting the cane, improved machinery for larger extraction of the juice and more skillful and economical ways of clarification and evaporation, would almost double the yield from the present acreage, which itself can be very greatly increased. In fact, the present consumption of sugar in the United States could easily be met by this section, provided the prices of sugar would justify the erection of factories by those having the capital-the cane could easily be grown. This section alone can grow sufficient cane to meet all the present demands for sugar in the United States, and, it is believed, will do so as soon as the price of sugar justifies putting so much capital into its factories.

\section{BOTANY.}

Sugar Cane, of which the botanical name is "saccharum officinarum," belongs to the large family of grasses. It is believed that all the cultivated varieties belong to one 
species. It has a gigantic stalk, ten to twenty feet long, usually straight in early growth, but bent, reclined or prostrate by its own weight or by winds, at maturity. It has, in common with all grasses, fibrous roots, which reach laterally in every direction, but never penetrate any great depths into soil. This penetration depends largely upon the character of the soil. In open, porous, sandy soils the roots go deeper than in loam, in which they penetrate further than in heavy clay.

The root stalk is a prolongation of the stalk, terminating in an attachment either to the mother cane (plant) or to the

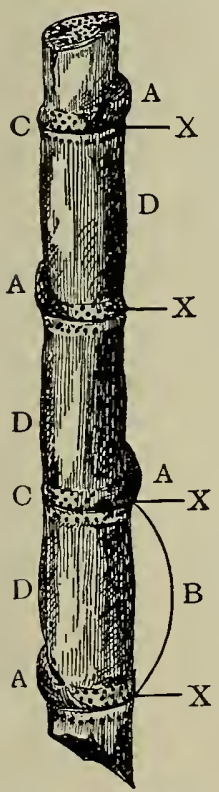

$B$, Joints of cane.

A, Buds or Eyes.

$\mathrm{D}$, Internodes.

C, No les.

$\mathrm{X}$, Semi-transparent dots in rows mother stalk (stubble). The true roots reach out laterally from this axis for food.

The cylindrical cane stalks vary in size according to variety, maturity and conditions of growth, and are composed of nodes and internodes (joints), which vary greatly in number and in length. Canes grown under adverse conditions have short joints, but those favored by a good season and fertile soil may produce joints six inches or more in length. Different varieties have, under similar conditions of growth, different lengths of nodes, and usually other merits being equal, the variety which has the longest nodes or joints is preferred.

The coloring matter, found only in the epidermis of the stalk, differs with the 
varieties, so that the stalk-color shades through white, yellow, green, red, brown, black, purple and even striped in two or more of these colors.

A wax called cerosin, usually found on the parts of the stalks adjoining the nodes, is mixed with the juice in the process of crushing the cane, but is removed during the clarification.

Large green leaves grow on alternate sides of the stalkclasping, but gradually ripen and fall off as the cane matures. Each leaf has a mid-rib, whitish in most varieties, highly colored in a few, with a channel-like depression on its upper surface. Sometimes the lower or clasping part of the leaf, the sheath part, is filled with minute prickers or stickers. In gathering such canes, the workmen need to protect their hands.

The joints mature, as previously stated, from the roots upward, and as each matures it casts its leaf, until, when in proper condition for harvest, the naked stalk has only a few leaves at its top.

At the base of each node, under the leaf, is a hard, shiny bud or eye, about the size of a cow pea. These eyes are the germs of future canes, used for the propagation of succeeding crops, and are surrounded by rows of dots, which produce roots when they are planted in moist soils. These roots are developed simultaneously with the bud, and furnish moisture and food to it.

In tropical countries, at maturity, the sugar cane sometimes flowers, or "tassels," that is, it sends out long pedun- 


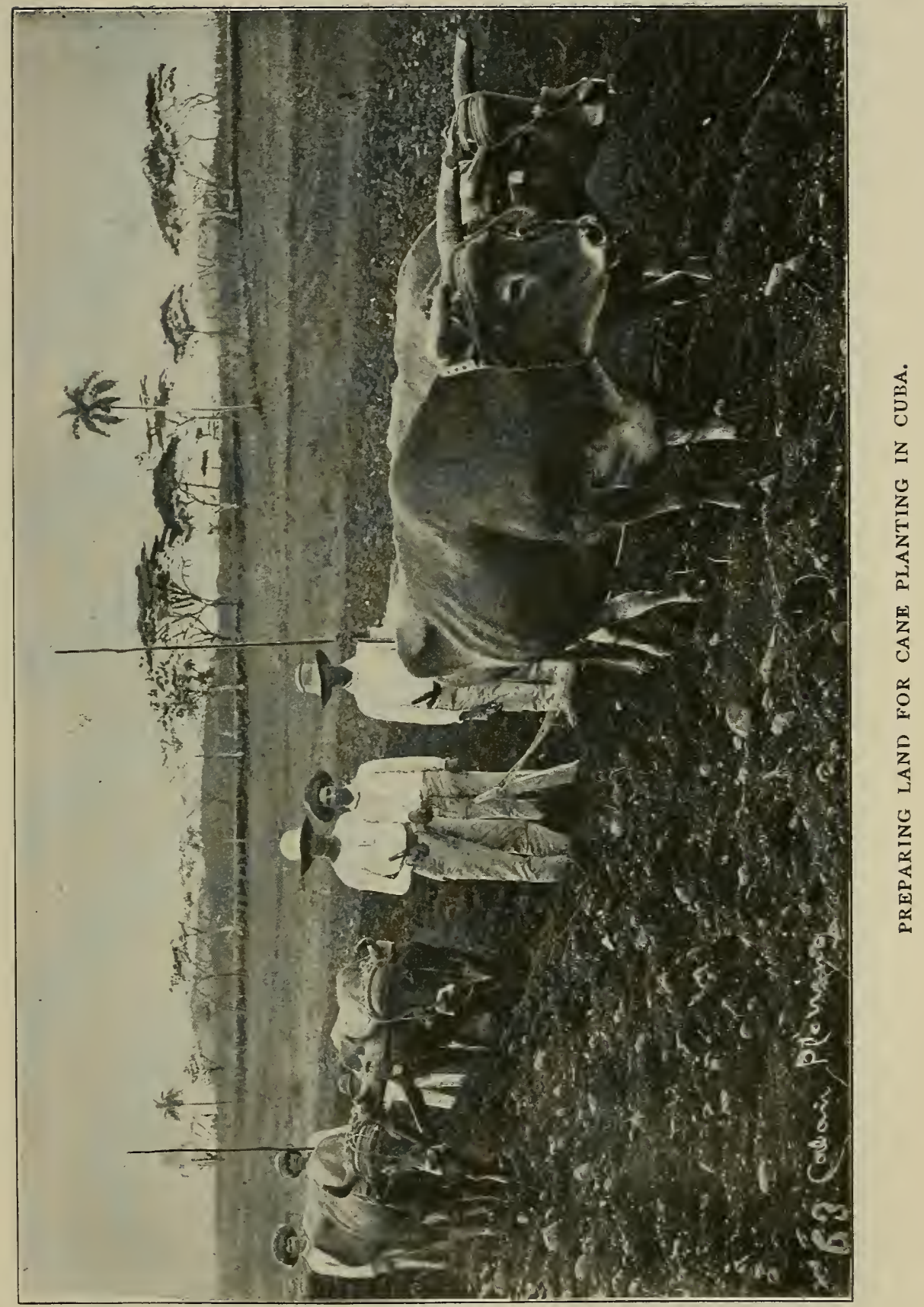




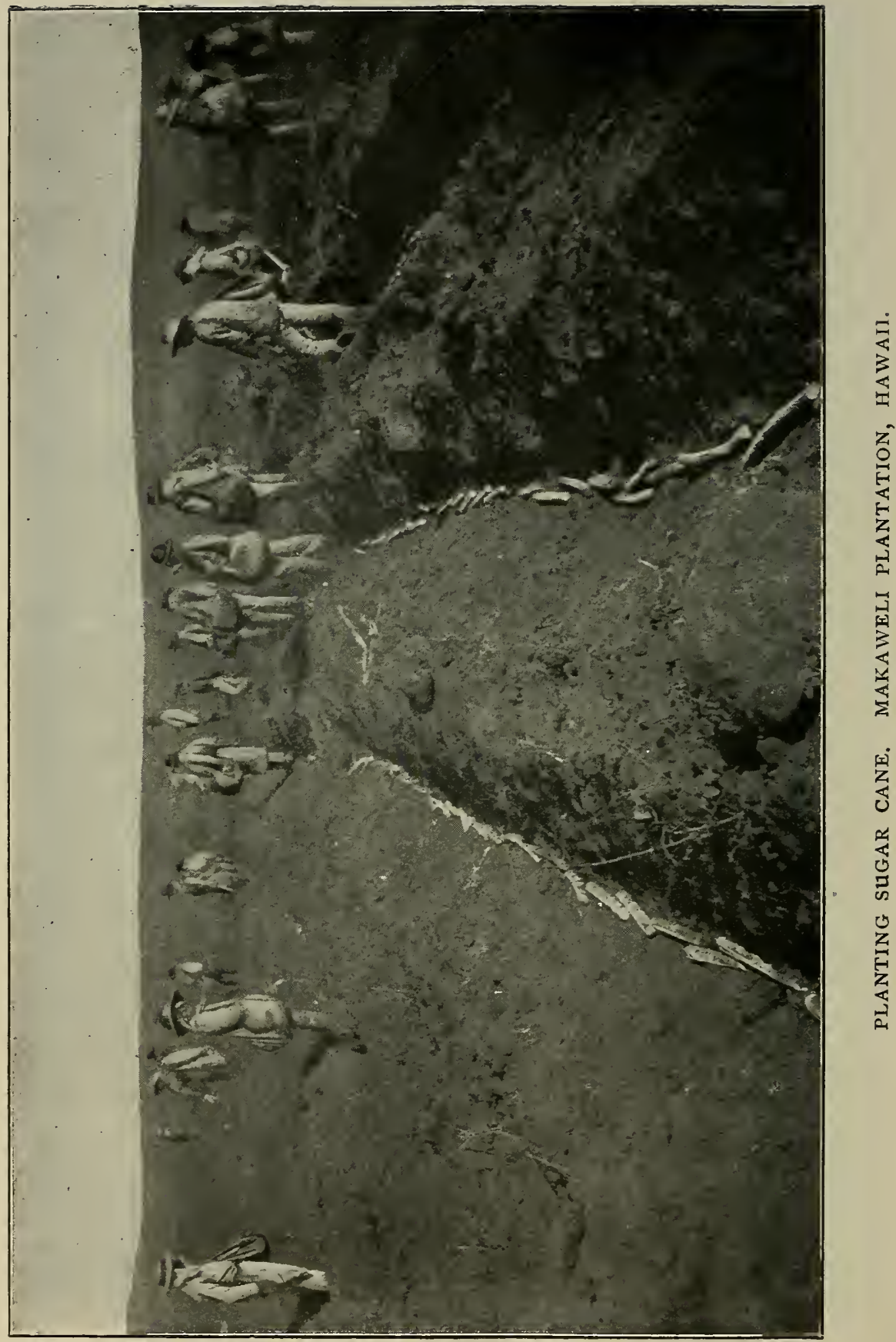


cles, each bearing a panicle of silken spikes. Each floriet in the spike has three stamens inserted in the ovary, but many seeds are infertile, possibly because cane has so long been propagated by cutting, that its flowers have lost vigor.

\section{ANATOMY.}

A cross section of cane under a powerful microscope reveals pith cells, usually six-sided, which contain nearly all its sugar. These cells are somewhat longer than thick, and constitute the greater part of the interior of the stalk. Distributed through them are groups of (fibro-vascular) bundles of tissue, which are composed of (I) vessels, through which water from the root, loaded with food, reaches the leaf, and (2) sieve-tubes, through which food from the leaf is distributed throughout the plant, and (3) bast tissues for strengthening the stalk. These bundles are much more abundant near the outer part of the stem, where the vessels and sieve-tubes are smaller in size and the bast tissues greatly increased to give additional strength and protection.

The upper part of each node and internode, or joint, is divided into two parts, the inner one forming the rind of the next joint above, and the outer one, uniting with the cells from within, forming the leaf. Just above the rows of root-dots around the stalk at the bud, is a light colored transparent narrow band, which clearly divides the lower from the upper joint.

The pith cells, which are so abundant in the internodes, 


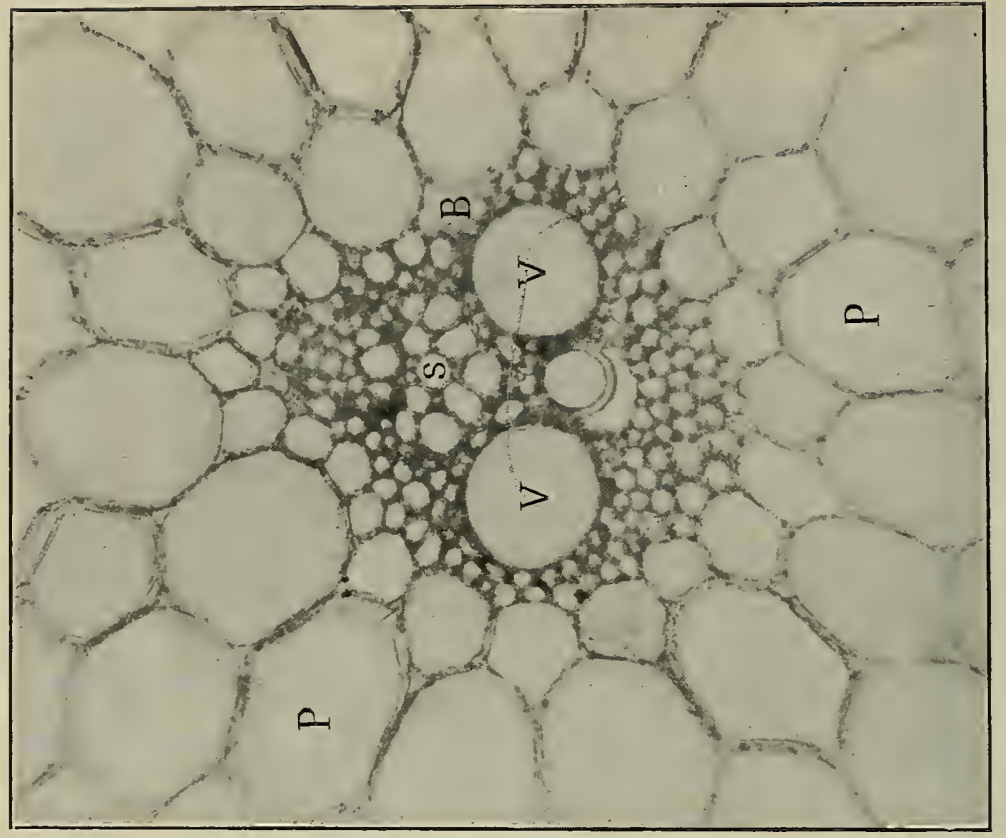

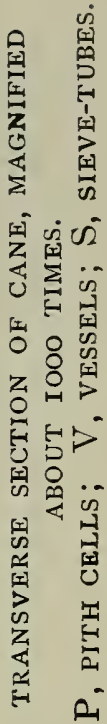

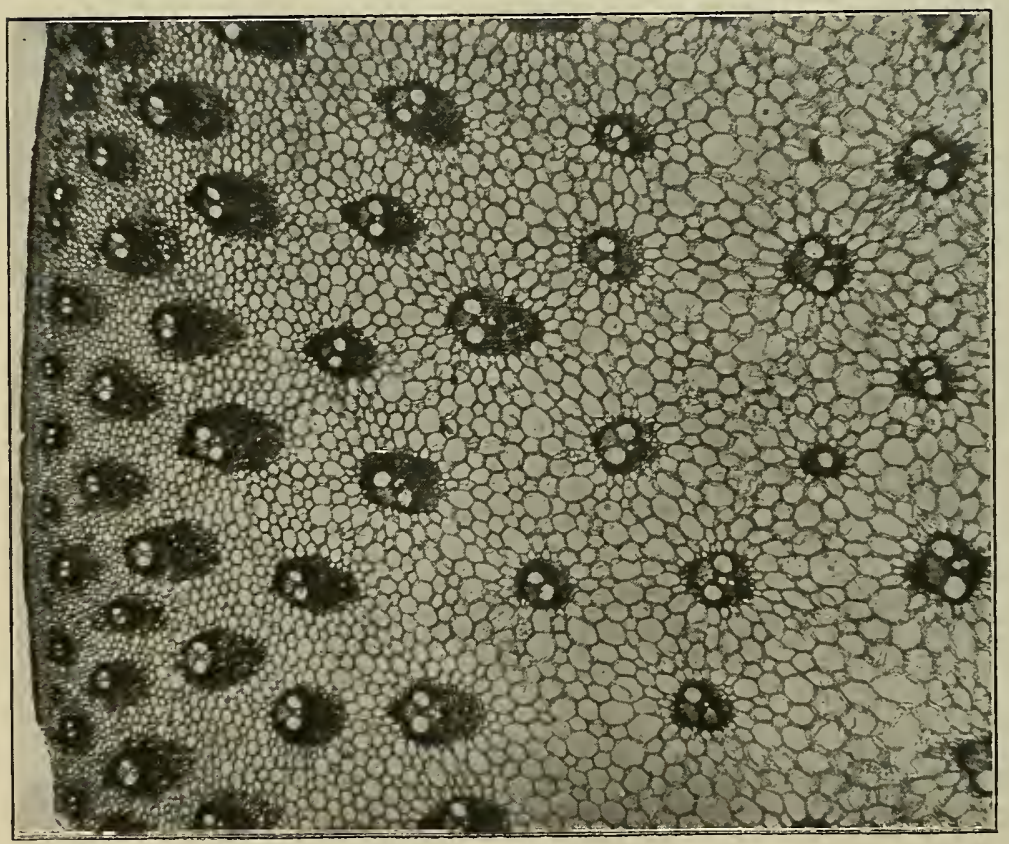

它 
almost disappear at the nodes, and are replaced by fibrovascular bundles.

The bundles of the stem pass into the leaf, and there meet thick short starch cells, surrounded by chlorophyll cells, which are not found in the stem. In these the food of the plant is elaborated. There are also wedge-shaped cells on the upper side of the leaf, which unroll the leaf as it comes out, and curl it during excessive evapcration, as in a drought.

\section{CLIMATE FOR CANE.}

It was once supposed that only tropical islands and peninsulas could successfully grow sugar cane, because they alone had the sea breezes laden with the particular salts required by the plant. It is now known that the accessibility of coast localities and their climatic conditions, caused them to be selected for growing cane; the heavy machinery needed in the manufacture of sugar could be easily and cheaply delivered there, and the cane products transported to other countries. Now, with cheap inland freights and abundant water by irrigation, the acreage of sugar growing may be many times multiplied, and countries which have only entered experimentally upon sugar culture, may develop into large producers.

Mexico, Central and South America have large areas capable of growing cane and might rapidly develop this industry, were the price of sugar satisfactory and their governments stable. Cuba has over twenty-five million 
acres, of which scarcely one million is under cultivation, and that devoted chiefly to sugar cane. There will be at least ten million acres of first class sugar land available when the system of railroads, now begun, is completed over the Island, but scarcity of labor, insecurity of capital, and the low price of sugar may prevent a rapid occupation of these lands as sugar estates. Louisiana and the Coast sections of Carolina, Georgia, Florida, Alabama, Mississippi and Texas are capable of producing vastly more cane than they do, for they have millions of acres, which, with little expense, can be brought under cultivation. Many of the West India Islands are languishing on account of the depreciated values of sugar estates, due to the low price of sugar combined with wasteful methods and mismanagement. A healthy rise in values would quickly bring capital to these Islands, and it, coupled with modern, scientific methods of growing cane and manufacturing sugar, would restore these steadily declining sugar countries to the conditions and positions of wealth which they once hold. In a broad and liberal discussion of the climate and countries adapted to cane growing and sugar manufacturing, one must admit that anywhere between $30^{\circ}$ to $35^{\circ}$ north and south of the equator it may be grown successfully, provided the water-supply (by rainfall or irrigation) and soil be satisfactory. Sugar cane is at present grown in the following countries:-Abysinia, Argentina, Queensland, New South Wales, Borneo, Bourdon and Reunion, Brazil, Cape Colony, Griana, Central America, Chili, China, Colombia, 
Egypt, India, Japan, Java, Madeira, Mauritius, Mexico, New Zealand, Natal, Fiji, Hawaii, Peru, Philipines, Siam, Spain, Straits Settlement, United States, Venezuela and West Indies. The cultivation extends from Spain $37^{\circ}$ north to New Zealand $37^{\circ}$ south on both sides of the equator.

Cane is a gigantic grass, requiring an enormous amount of moisture for its best development. An abundance of rainfall, distributed throughout the growing seasons, or its equivalent in irrigation, is one of the essential conditions, for sixty inches of rainfall, properly distributed, are considered necessary to produce a good crop. Of course irrigation answers the same purpose, and, as practised in Hawaii, produces the enormous average yield of over eleven tons of sugar per acre on one estate.

\section{DRAINAGE.}

While it is true that sugar cane requires a large amount of water for its best development, it is also true that a well drained soil is absolutely essential to vigorous growth and large matured canes. These require large quantities of nitrogen for perfect growth, and it is largely furnished to them by nitrification. This is due primarily to microbes, but an abundance of air, a moderate amount of moisture, the presence of a little alkali and organic matter containing nitrogen, are necessary to promote this action. Only well drained soils are thoroughly aerated, retentive of capillary moisture, and free from organic acids. 
Nitrification, or feeding on nitrogen of the air by soildwelling microbes, is so intimately dependent upon good drainage, that without such drainage it is all but impossible and a cane crop is a certain failure if planted upon undrained lands.

Drainage is accomplished either by open ditches or tiles. Open ditches should be sufficiently deep, wide and numerous to carry off the heaviest rainfalls and retain the bottom or ground water at a constant depth of 3 to 4 feet below the soil. Excellent results are obtained by a system of ridged rows with numerous quarter-drains, emptying into open ditches, but many objections can be raised against them, among which are the large annual expenses of keeping them cleaned out and their banks free from weeds and bushes, and the loss of land, amounting in some countries to one-tenth and one-twelfth of the area cultivated. The difficulty of cross-plowing the lands when breaking, and the imperfect work on the ditch bank rows during cultivation, are minor but real and substantiai objections.

Tile drainage is far superior to open ditches, where such a fall can be obtained that the water will keep them clean. The great objection to tiles is their first cost, but this has to be incurred but once. Experience has shown the great superiority of tiles over open ditches, from the flushing of the land to the harvesting of the crop. Plowing is more easily performed, the soil in the spring heats more quickly, moisture is better conserved in a drought, cultivation is easier and leaves the soil in better condition and the yield 


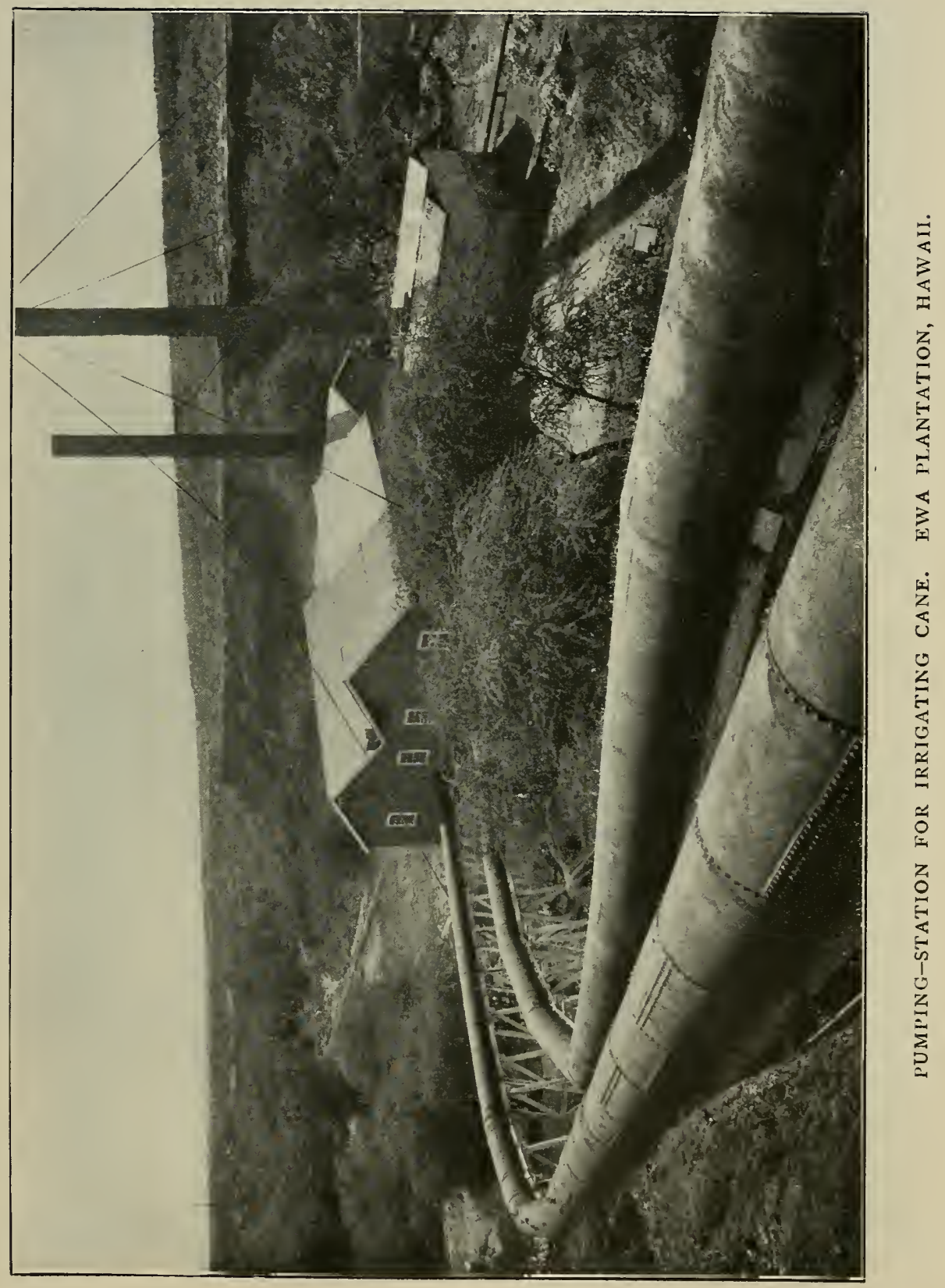




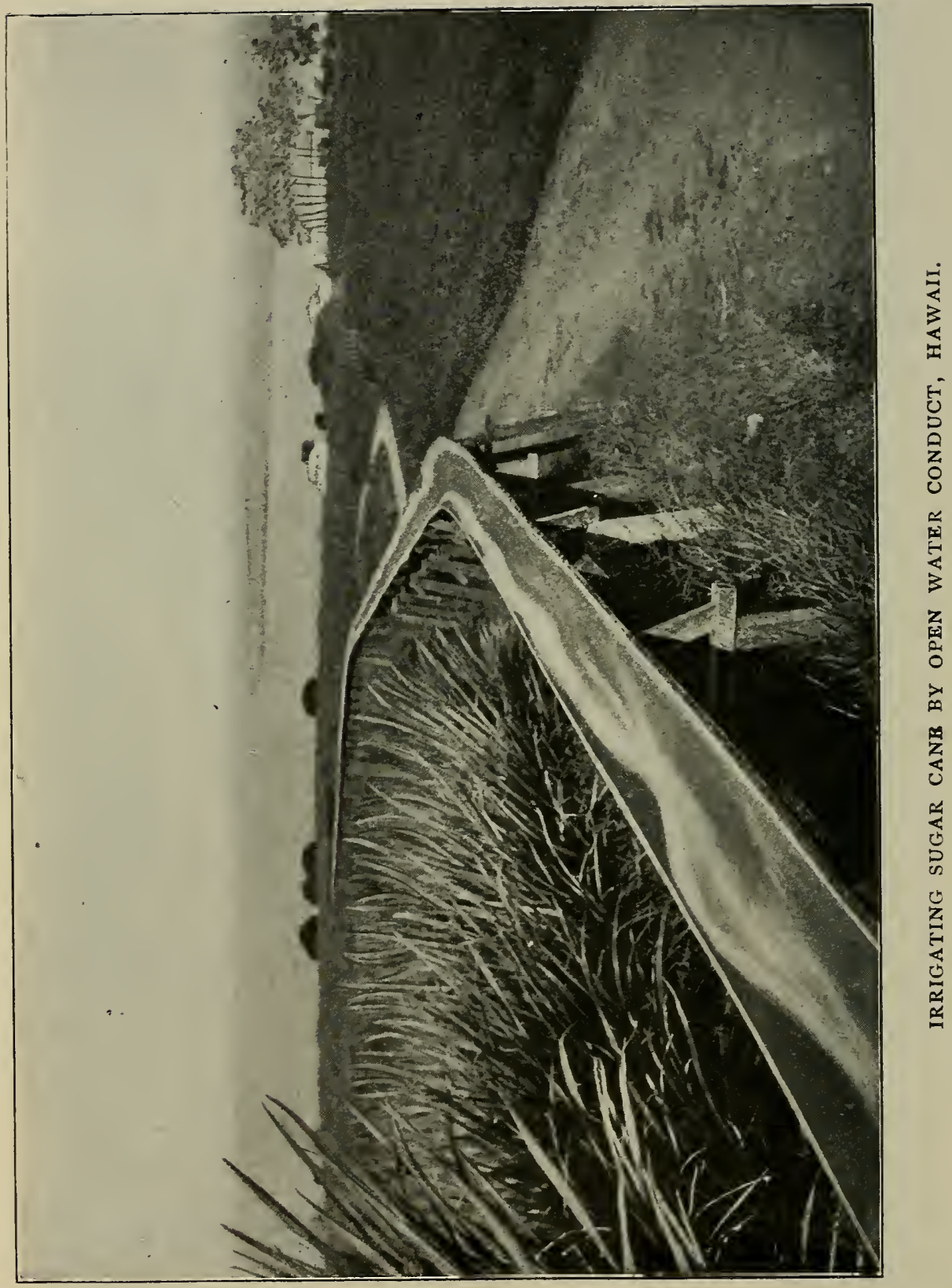


of the crop is much larger. All of these are practical benefits, in addition to the increased area of the land, and the saving of the numerous and continuous expenses and annoyances incident to open ditches and quarter-drains. Tile drainage, wherever the soils permit it, not only repays a handsome interest upon the investment, but also each year gives a surplus for a sinking fund, which, in a short, time will liquidate the principal, if it were borrowed for the construction. The tiles should be laid only by experienced engineers, well acquainted with the soils and climate of the country.

It is impossible too strongly to emphasize the importance of good drainage of all sugar lands.

\section{IRRIGATION.}

While drainage is imperatively needed in many places, irrigation is as important in others where the rainfall is deficient. There are few places where the rainfall is ample and so well distributed throughout the season as to produce maximum crops. The history of nearly every country which depends upon rainfall for its water supply, shows that maximum crops are rarely obtained, and that an overwhelming majority of crop failures follow droughts prevailing at some time during the growing period, all of which indicates that even in places which have a large annual rainfall, irrigation may be used with enormous profits.

Water is esssential to all crops, and is needed for their 
growth and to transport the other chemical ingredients through the plant. For every pound of dry matter produced in the cane 400 to 500 pounds of water pass through the plant and evaporate by its foliage. A crop of 45 tons of cane per acre (cane and its accompanying tops and leaves) contains at least i 6 tons of dry matter, and, using the minimum amount per ton given above, evaporates during its growth, from the foliage alone, the enormous quantity of 6,400 tons of water; this takes no account of the large amount evaporated from the soil. To supply this evaporation through the foliage, requires a rainfall of over $5^{6}$ inches, distributed through the growing season; such fall and distribution are rare in any country.

In Hawaii, where irrigation is highly successful, many interesting results have been obtained at the Experiment Station under the direction of Dr. Walter Maxwell and his successor Mr. R. E. Blouin. These results show that it requires from 75 to ror gallons of water to produce I pound of sugar. In one instance, where by irrigation the equivalent of two inches of rainfall was given weekly through the season to a plot previously fertilized by 138.6 pounds nitrogen from nitrate of soda and 157.5 pounds of potash as sulphate of potash, the yield was the enormous amount of 54,605 pounds of sugar per acre. The quantity of water required was 5,515,453 gallons, or an average of Ior gallons for each pound of sugar, but it is especially to be observed that an abundance of water enables cane to attain a maximum growth and yield of sugar only when supplied 


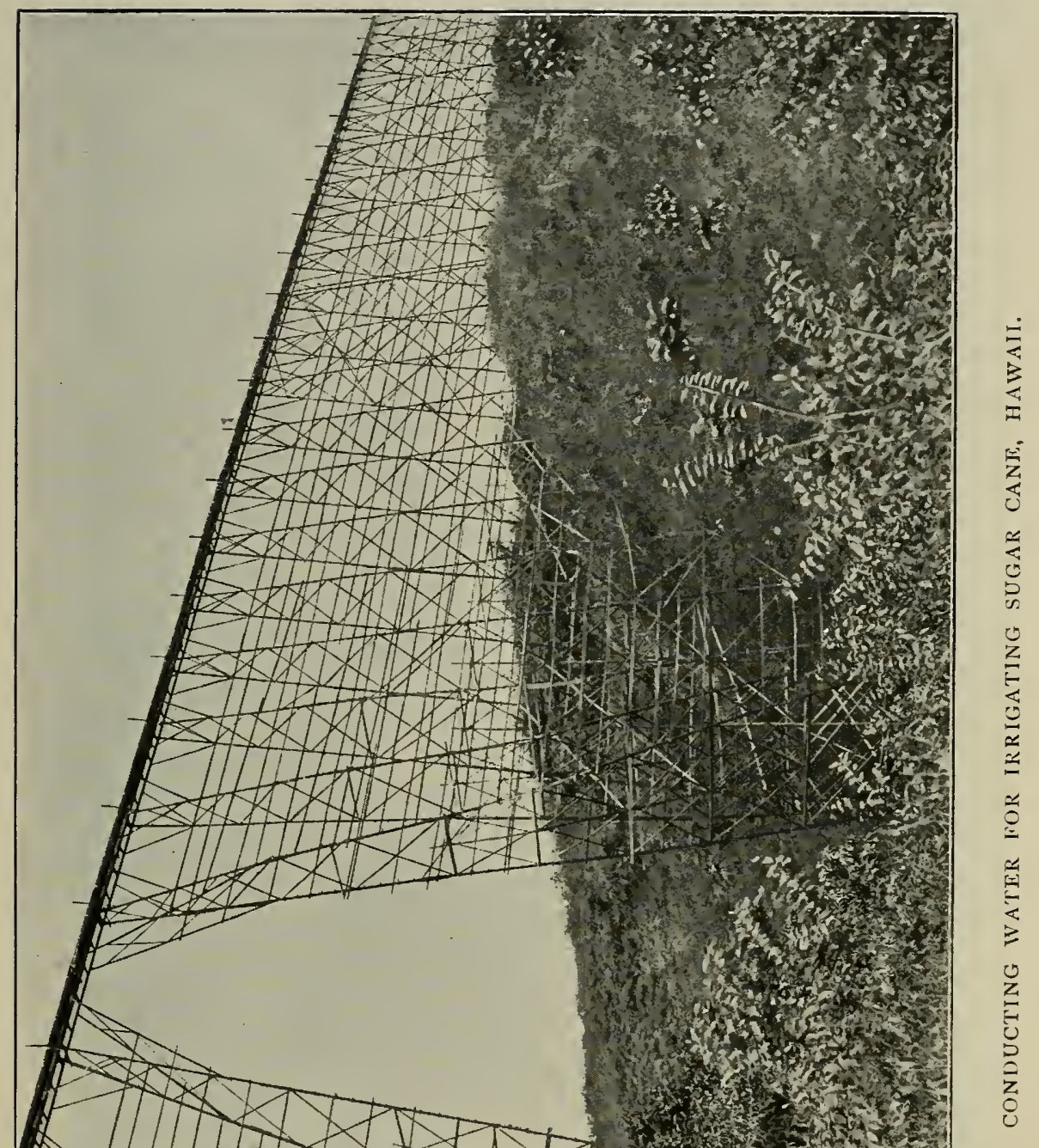




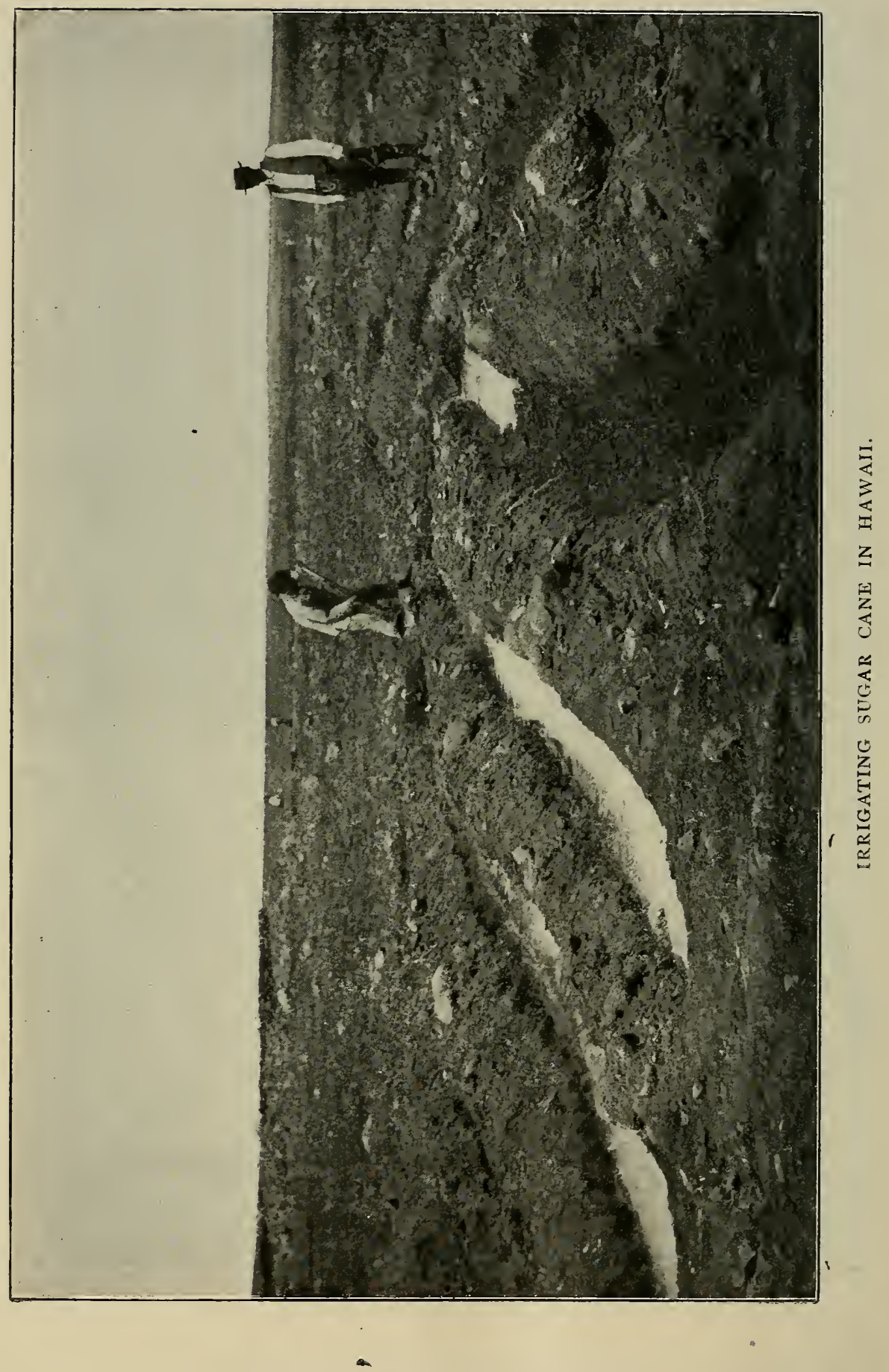


with sufficient plant food,-potash, phosphoric acid and nitrogen. It is by the liberal use of fertilizers, in connecttion with irrigation, that the enormous yields of Ewa Plantation in Hawaii have been obtained.

\section{VARIETIES OF CANE.}

There are many varieties of cane, so that the whole range takes in almost every conceivable characteristic, and each country has its favorite variety, which is generally planted, as :-

In Cuba and many of the other West India Islands, Mexico, and Central and South America, the Bourdon or Otaheite (Tahiti); in Hawaii, the Lahaina, though the Rose Bamboo is also found in its sugar fields; in Louisiana, the purple striped and its offspring, the purple, though a few estates use exclusively the light Java, locally known as "La Pice;" in Mauritius and Reunion, the Loucier, similar if not identical with the Otaheite, is a favorite; in Java, the Cheribon or Purple and the light Java; in Queensland a light green variety known locally as the light Caledonian.

These may be considered the staple varieties of these respective localities, but it is not to be inferred that no others are grown; nearly everywhere others are on trial by the Botanical Gardens, Experiment Stations or progressive planters. 


\section{SEEDLINGS.}

Until recently new varieties were produced by nature only at rare intervals, through what are usually termed "bud variations,"- - a few of decided merit have thus had their origin.

About twelve years ago, and nearly at the same time, Messrs. Harrison \& Bovell in Barbados and De Soltwedel of Java discovered that cane seed, hitherto looked upon as imperfect and barren, were, some of them, capable of plantproducing. This discovery led to others, and among them that some varieties arrow with great regularity, and, by cross-fertilization, produce a good quantity of fertile seed, and that the product from each seed has its own peculiar properties, and affords opportunity for "seed selection." Many such promising seedlings have been developed and are now on trial in nearly every sugar country. Dr. Kobus, Director of the Oost Java Sugar Experiment Station, reports that over 15,000 acres of selected seedlings are now under cultivation in Java, and they are also being tested in many other countries; but it is by no means to be understood that cane seed is used for general planting. They are too small and too many of them infertile and their plant variation too great to permit of this practice. Now and then a seed-produced cane is valuable as against large numbers of worthless ones, so a harvest from such a general planting would contain no end of varieties, mostly without merit or 


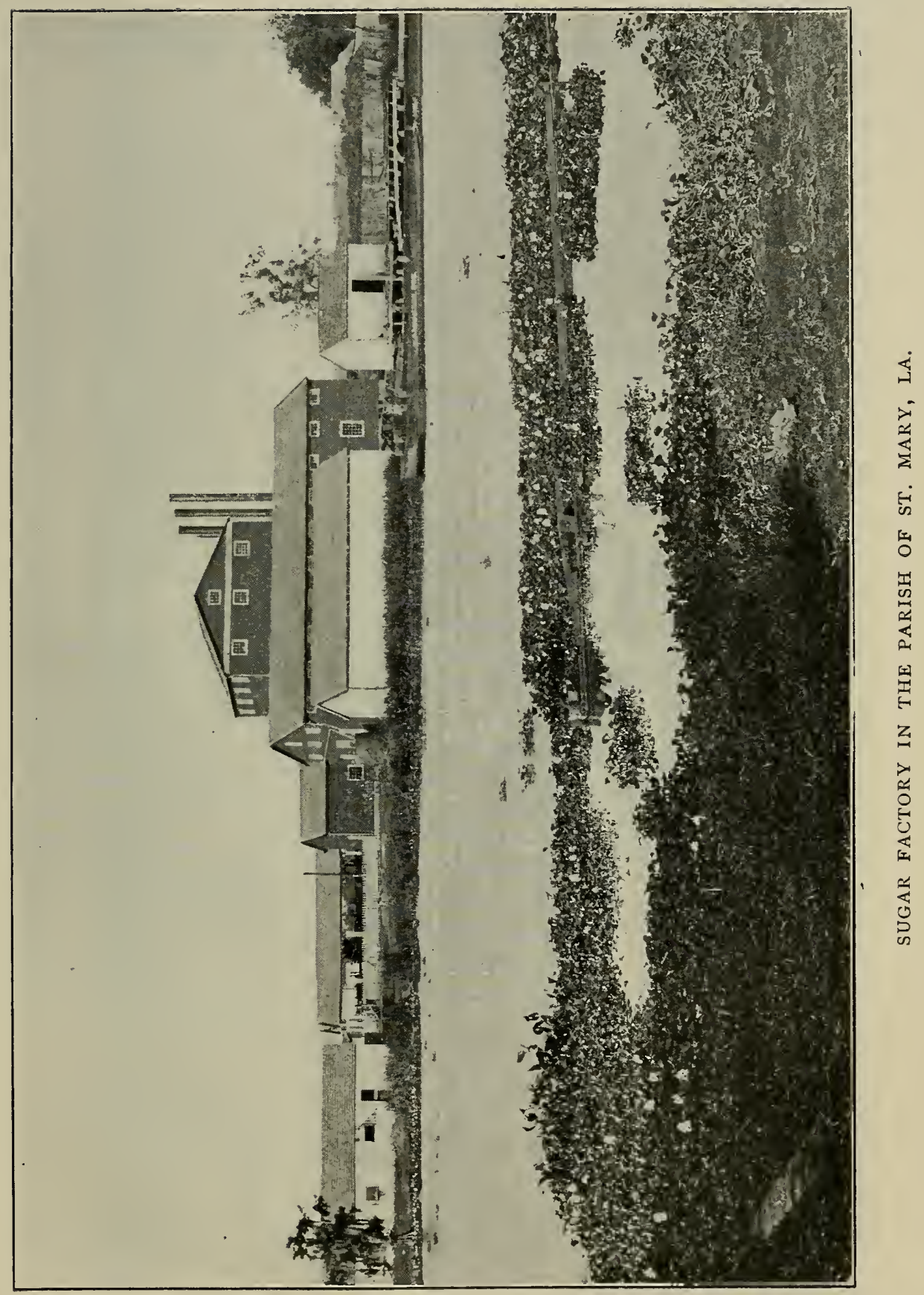




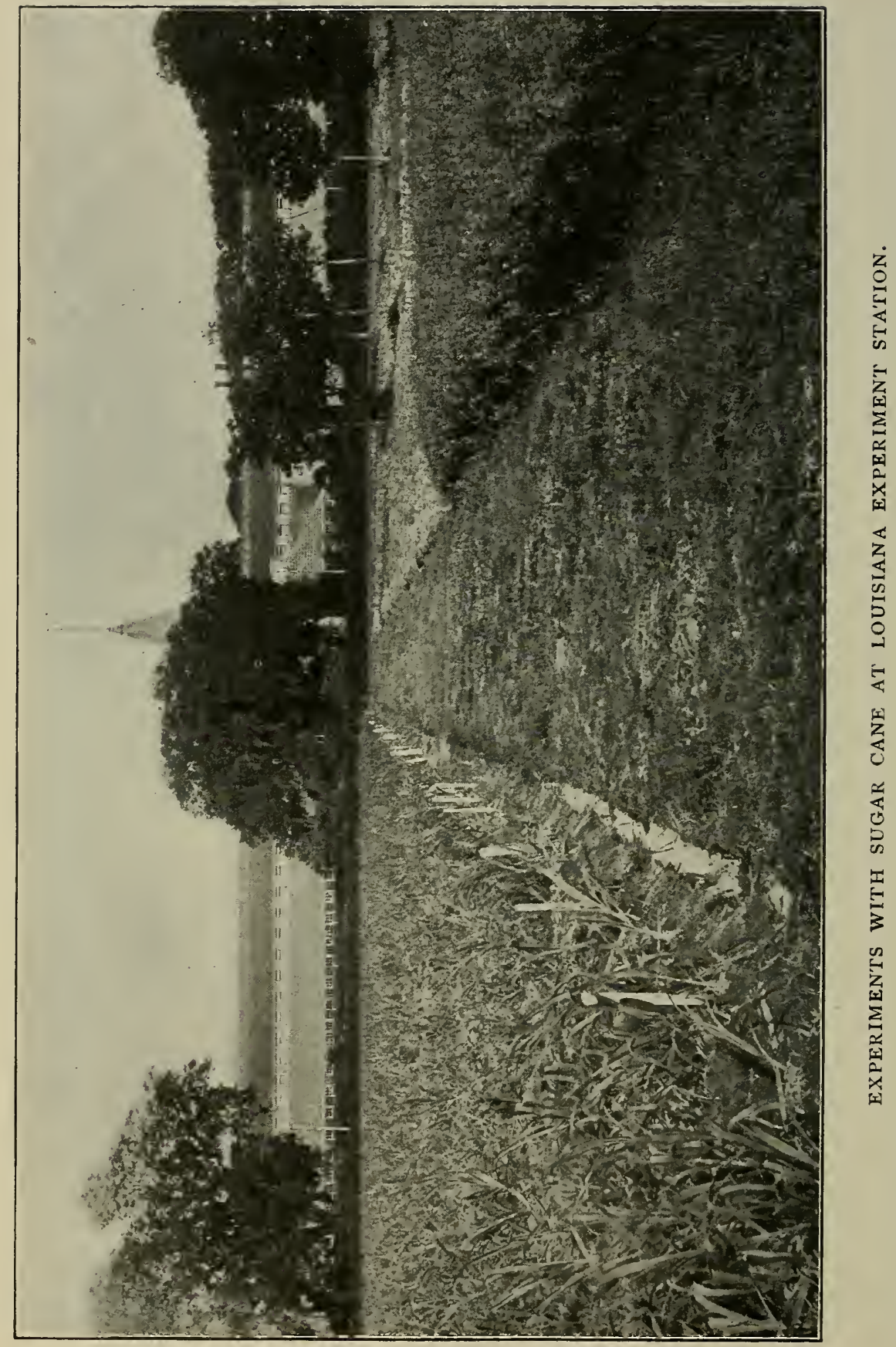


profit. In the practical, scientific search for valuable varieties, the seeds are planted in a nursery, the young plant transplanted to the field, and each one carefully studied by a trained chemist. When one is found to combine desirable qualities, it is propagated by cuttings (boutures), and if its merits seem sufficient to justify such action, it is then distributed to planters for trial. In this way different varieties of known worth are crossed for the purpose of obtaining canes which possess vigor, sugar rich in quantity and quality, and disease-resisting vitality.

\section{SOILS FOR SUGAR CULTURE.}

Cane-growing soils in the different countries vary in chemical composition and physical properties, but, as a rule, those rich in plant food, with a large water holding capacity, are best. Where irrigation is not practised, clay or heavy loam, capable of carrying a large amount of moisture, is to be selected, and even with irrigation, the soil must be sufficiently retentive to prevent rapid percolation and consequent financial loss, because of many expensive irrigations and washing away of soluble plant food.

Fertile soils have always an abundance of humus or vegetable matter. Tropical soils, subject to heavy rainfalls which stimulate luxuriant vegetation, are almost universally adapted to the growth of sugar cane The vegetation, in its transformation into humus, furnishes organic acids 
which decompose the soil particles into very fine earth. Such soils, in course of time, become rich in organic matter, which supplies nitrogenous food, as well as in very finely divided earth, with its mineral supply. Both, but especially the humus, retain the excessive moisture essential to healthy, profitable cane-growing.

Hawaiian Soils. As before stated, the heaviest acre yields of sugar in the world are in the irrigated districts of Hawaii. Dr. Maxwell has shown, that the average soil of these Islands contains from .3 to .4 per cent. lime, .3 to .35 per cent. potash, .I 8 to .5 i per cent. phosphoric acid, and . 7 to .54 per cent. nitrogen. Such fertility, under correct, systematic irrigation and fertilization, yields from six to fifteen tons of sugar per acre. It is of volcanic origin, and derived from basaltic lava, emitted within recent geological epochs, "primitive in character," and chemically closely resembling the rocks whence it came. Dr. Maxwell makes three classes :-

I. Dark red, derived from the normal lavas by weathering in a climate of great heat and dryness.

2. Yellow and light red (inferior to the dark red), derived from a class of lavas which suffered great alteration through the action of steam and sulphurous vapors at the time of emission.

3. Most fertile of the three, sedimentary deposits washed down upon the coral reefs which begirt the Islands.

These soils in texture resemble pulverized brick, have 
very little silica, and are without the plasticity generally characteristic of sugar soils, but they are easily worked and yield enormously when properly fertilized and irrigated.

Queensland. The Mackay district is deficient in lime, and the Isis soils in potash.

Demerara. The cultivated parts of British Guiana are the heavy clay alluvial coast lands. During very protracted droughts they sometimes shrink or harden by contracting into expanses of intersecting cracks, often to the great injury, or even destruction, for the time being, of all plant life. Their analyses by Prof. Harrison show less than 20 per cent. of sand, which is in the form of an impalpable powder, .084 per cent. to .II3 per cent. nitrogen, .074 per cent. to.I 55 per cent. phosphoric acid, .382 per cent. to .575 per cent. potash and .I84 per cent. to .566 per cent. lime, and the natural conclusion is that physical improvement by proper drainage and cultivation is their great need.

Trinidad and Jamaica sugar lands are somewhat similar to those of Demerara, being stiff clay or reddish clay, overlying limestone, which contains over .5 ver cent. potash and nearly .2 per cent. phosphoric acid.

Antigua ranges from heavy clay, from compact volcanic ashes, to the various decomposed products or tertiary rocks; analysis of the former shows agricultural clay (fine silt and clay) present to the extent of two-thirds of the soil,-lime is abundant, over .9 per cent. to 3.18 per cent., potash rather low, .092 per cent. to .32 per cent., nitrogen fair, 
.086 per cent. to .1I 4 per cent., phosphoric acid low, .06 I per cent. to .I per cent.

St. Kitts is sandier, poorer in lime, .54 per cent., slightly richer in potash, . I 27 per cent., and lower in nitrogen, .064 per cent.

Cuba and Java contain every shade of soil from the rich alluvium of the coast, through the tertiary and secondary geological formations, to the volcanic or primary rocks, of the extreme mountain ranges. As a rule, the alluvium of the coast furnishes their largest and best sugar areas, and the two islands together are the largest cane sugar producers in the world.

Cuba has long been known as the "Gem of the Antilles," the island "par excellence" for sugar cane. The small part of it under cultivation has produced over a million long tons of sugar in a single year, but on a per acre basis that has been an extremely small amount when compared with the enormous returns in Hawaii. This relative discrepancy is especially impressing when account is taken of productiveness of the soil, the excellence of the climate, and the all but perfect conditions for growing sugar cane in Cuba. To state the case in another way, Cuba's soil and climate are vastly superior, but Hawaii's yield per acre is far in the lead. A study of the methods of the two countries discloses the reason. Both have modern, scientific sugar houses, and skilled mechanics and sugar makers, and obtain about the same amount of sugar from each ton of cane ground, so the difference is not in manufacturing, but in growing. 
Hawaii uses fertilizers in large quantities and of approved composition, steam-plows and present-day agricultural implements, and cultivates thoroughly and intelligently. Over two-thirds of the entire area devoted to cane in Hawaii is plant cane, less than one-third is rattoon, and of this third but little is carried beyond one year. A stubble crop with a yield of less than thirty tons of cane per acre is considered unprofitable. The secret of success in Hawaii is the application of business methods, the use of fertilizers and the frequent replanting of the fields in cane. In Cuba, the deplorable conditions which now prevail must give way to improvement caused by example and competition, and it is a safe prediction that the progressive methods of fertilization and cultivation of Hawaii will be introduced and make this island what it deserves to be-"the sugar-bowl of the world." Sugar cane will then, as it did until recently, furnish the world's sugar, much of which, comes now from the sugar beet.

Louisiana, which grows more sugar cane than any other one of the United States, owes its superiority, in this respect, to the surpassing fertility of the delta of the Mississipi and its out-lying bayous. The alluvium of this section is of recent origin, formed from the best soils of over a score of states which extend from the extreme heights of the Appalachians on the east to the Rockies on the west. This soil detritus, mixed and commingled by running water, deposited under sunny skies, forms an area of perhaps the richest soil in the world. It is silty or loamy clay of varying 
physical and chemical composition, which was determined by the geologic place whence it came and the force which deposited it. It must be thoroughly drained before a maximum yield can be expected. This is accomplished by a system of canals, panel (cross) ditches and parallel ditches, quarter drains and ridged rows, to be described further on.

The Red River and its outlying bayous, the Teche, Boeuf, Rapides, De Glaze, etc., have continuous alluvial bottoms of red sand and clay, extremely fertile, easy of cultivation and susceptible of good drainage, on which some of the best sugar estates are located.

The prairies of the southwestern part of the state are derived from old bluff hills, which once skirted the western edge of the then Mississippi River and are similar to those of East Baton Rouge, on the eastern side of the river, where much cane is grown. These soils are brown loams, mainly silts, and very productive. The foliowing is about the average of the three types described above:

Mississippi Alluvial,-.2 to i. per cent. lime;. . to .9 per cent. potash; .07 to .2 per cent. phosphoric acid, and .08 to . I 5 per cent. nitrogen.

Ren River Alluvial, -2 to 3 . per cent. lime; .08 to .2 per cent. potash;.09 to .I 2 per cent. phosphoric acid, and .06 to .I per cent. nitrogen.

Bluff Prairie,-. I 2 to . 4 per cent. lime; .I to .2 per cent. potash; .06 to I 3 per cent. phosphoric acid, and .07 to 1.2 per cent. nitrogen.

The Texas sugar lands of Oyster Creek and the Brazos 
bottoms are similar in origin and composition to those of the Red River.

Atlantic Coast Belt. A large area, usually styled the piney woods coast belt, extends from Carolina to Texas on the Atlantic and Gulf coasts. Its soil is sandy and welldrained, but in spite of its being thin and poor, sugar cane is grown in small quantities throughout its entire extent. The cane is converted into syrup mostly for home consumption, still a considerable surplus is marketed in the north and west. Great improvement is being made and fairly good cane crops raised by the judicious rotation of other crops and an intelligent use of fertilizers. The industry is constantly growing and gives promise of soon becoming second in value to the cotton crop alone. Nowhere, perhaps, are the effects of commercial fertilizers more marked than on these very soils which annually use many tons of them.

\section{COMPOSITION OF CANE.}

Cane varies in its chemical composition, which depends upon many influences, such as variety cultivated, country where grown, soil, season and maturity. In I,ouisiana and other southern states of the United States, it varies with the quantity grown upon an acre, the time of harvests, and whether plant or stubble.

Prof. Stubbs, at the Louisiana Sugar Experiment Station, found that a ton of purple cane, cut for the mill, had $\mathbf{I}_{35}$ 
lbs. roots, 844 lbs. leaves, and 532 lbs. tops, or a total of I 5 I I lbs., making with the ton of cane 35 I I lbs.

A ton of striped cane had, similarly, I I 3 lbs. roots, 656 lbs. leaves and 385 lbs. tops, or I, I 54 lbs., making with the ton of cane $3, \mathrm{I} 54 \mathrm{lbs}$.

The following table shows the valuable soil ingredients removed by a ton of cane and its roots and foliage :

\section{Purple cane.}

\begin{tabular}{|c|c|c|c|c|c|c|}
\hline & NITROGEN. & $\begin{array}{l}\text { PHOS- } \\
\text { PHORIC } \\
\text { ACID. }\end{array}$ & POTASH. & LIME. & $\begin{array}{l}\text { MINERAL } \\
\text { MATTER. }\end{array}$ & $\begin{array}{l}\text { ORGANIC } \\
\text { MATTER. }\end{array}$ \\
\hline 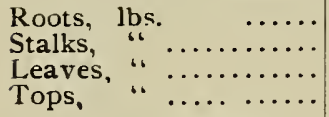 & $\begin{array}{l}0.17 \\
1.08 \\
0.72 \\
1.01\end{array}$ & $\begin{array}{l}0.10 \\
1.04 \\
0.30 \\
0.19\end{array}$ & $\begin{array}{l}0.09 \\
1.22 \\
0.69 \\
0.52\end{array}$ & $\begin{array}{l}0.14 \\
0.52 \\
1.32 \\
0.56\end{array}$ & $\begin{array}{r}2.99 \\
11.18 \\
20.17 \\
10.29\end{array}$ & $\begin{array}{r}31.48 \\
407.14 \\
134.66 \\
8419\end{array}$ \\
\hline Total....... & 2.98 & 1.63 & 2.52 & 2.54 & 44.63 & $65 \% .47$ \\
\hline
\end{tabular}

\section{Striped cane.}

\begin{tabular}{|c|c|c|c|c|c|c|}
\hline & NITROGEN. & $\begin{array}{l}\text { PHOS } \\
\text { PHORIC } \\
\text { ACID. }\end{array}$ & POTASH. & LIME. & $\begin{array}{l}\text { MINERAL } \\
\text { MATTER. }\end{array}$ & $\begin{array}{l}\text { ORGANIC } \\
\text { MATTE } 1 .\end{array}$ \\
\hline 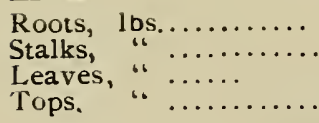 & $\begin{array}{l}0.17 \\
0.88 \\
0.55 \\
0.78\end{array}$ & $\begin{array}{l}0.10 \\
1.30 \\
0.26 \\
0.41\end{array}$ & $\begin{array}{l}0.19 \\
2.34 \\
1.13 \\
0.52\end{array}$ & $\begin{array}{l}0.11 \\
0.58 \\
1.04 \\
0.20\end{array}$ & $\begin{array}{r}2.81 \\
12.40 \\
17.95 \\
8.43\end{array}$ & $\begin{array}{r}29.81 \\
392.52 \\
102.40 \\
63.51\end{array}$ \\
\hline Total. & 2.38 & 2.07 & 4.18 & 2.03 & 41.59 & 588.24 \\
\hline
\end{tabular}

In plantation growing the roots are left in the ground, and, if the tops and leaves are plowed under, a ton of cane only removes what is contained in the stalks; that is to say, for the purple variety, I.08 lbs. nitrogen; I.04 lbs. phosphoric acid; 1.22 lbs. potash, and 0.52 lbs. lime. For the striped, .88 lbs. nitrogen; I.30 lbs. phosphoric acid; 2.34 lbs. potash and $0.5^{8} \mathrm{lbs}$. lime.

If the leaves and tops be burned in the field,- a custom 
prevailing in Louisiana,-the nitrogen in them is dissipated, and the other mineral ingredients returned to the soil. The nitrogen removed will then be, for the purple cane, $2.8 \mathrm{I}$ lbs. per ton, and, for striped, $2.2 \mathrm{r} \mathrm{lbs}$., and the entire loss for the former variety, $2.8 \mathrm{r}$ lbs. nitrogen, $\mathrm{r} .04 \mathrm{lbs}$. phosphoric acid, $1.22 \mathrm{lbs}$. potash, and $.52 \mathrm{lbs}$. of lime; and for the latter $2.2 \mathrm{I}$ lbs. nitrogen, r.3० lbs. phosphoric acid, $2.34 \mathrm{lbs}$. potash and .58 lbs. lime.

Dr. Maxwell gives analyses of Rose Bamboo and Lahaina varieties and their trash as grown in Hawaii as follows:

Rose Bamboo:-Nitrogen .074 per cent., potash .144 per cent., phosphoric acid .045 per cent., lime 0.40 per cent.

Lahaina:-Nitrogen .077 per cent, potash .077 per cent., phosphoric acid .03 I per cent., lime .03 I per cent.

In the dried trash there were in :

Rose Bamboo:-Nitrogen .53 per cent, potash I 30 per cent., phosphoric acid .I 3 per cent., lime .47 per cent.

Lahaina:-Nitrogen .42 per cent,, potash I.36 per cent., phosphoric acid .I t per cent., lime .44 per cent.

In the report for 1900 the yields (including trash) and analyses of many varieties are given; by calculation the following amounts are found to have been removed by each ton of cane, and its trash:

\begin{tabular}{|c|c|c|c|c|}
\hline & NITROGEN. & $\begin{array}{l}\text { PHOS- } \\
\text { PHORIC } \\
\text { ACID. }\end{array}$ & IOTASH. & LIME. \\
\hline 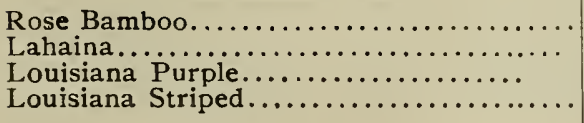 & $\begin{array}{l}5.9 \mathrm{lbs} . \\
3.9 \text { ، } \\
7.1 \text { “ } \\
4.8\end{array}$ & 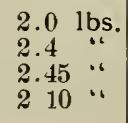 & 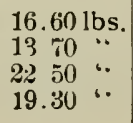 & $\begin{array}{l}5.0 \mathrm{lbs} \\
4.4 \quad \ldots \\
70 \\
4.4\end{array}$ \\
\hline
\end{tabular}


Extensive investigations as to the composition of sugar cane, were made by Prof. Prinsen Gerlichs and Prof. Potter of Java; their figures for a ton of cane, with trash are : 2.72 lbs. nitrogen, 2.22 lbs. phosphoric acid, 8. Io lbs. potash and I.93 lbs. lime. On the same basis, Kruger gives for Cheribon 2.I lbs. nitrogen, 4.3 lbs phosphoric acid, 4.3 lbs. potash and r. 8 lbs. lime.

C. J. von Lockeren, of Java, gives the following table on the basis of the yield of an entire acre:

\begin{tabular}{|c|c|c|c|c|}
\hline & NITROGEN. & POTASH. & $\begin{array}{l}\text { PHOS- } \\
\text { PHORIC } \\
\text { ACID. }\end{array}$ & LIME. \\
\hline 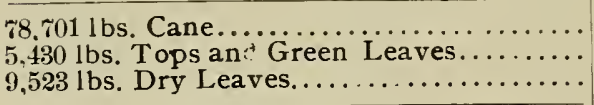 & $\begin{array}{l}40.9 \\
10.5 \\
23.6\end{array}$ & $\begin{array}{l}85.0 \\
33.5 \\
52.6\end{array}$ & $\begin{array}{r}40.1 \\
4.9 \\
77\end{array}$ & $\begin{array}{r}16.5 \\
4.9 \\
50.5\end{array}$ \\
\hline Total. & 75.0 & 1711 & 52.7 & 719 \\
\hline
\end{tabular}

From these reliable conclusions, based on experiments in countries far apart, the following general deduction may fairly be made: The amount of fertilizing ingredients taken up by a ton of cane and its accompanying foliage, etc. varies greatly in different soils and climates, and the percentage of stalks to foliage takes as wide a range. In Louisiana the foliage to a ton of stalks is much greater than in tropical countries, while the dry matter in the trash is much less than that in the cane.

In Hawaii, Dr. Maxwell found the latter to be to the former as 44 and 47 is to $5^{2}$, showing that the composition of the foliage varies with the variety, age and climate, and that the ash changes in quantity and composition as the 


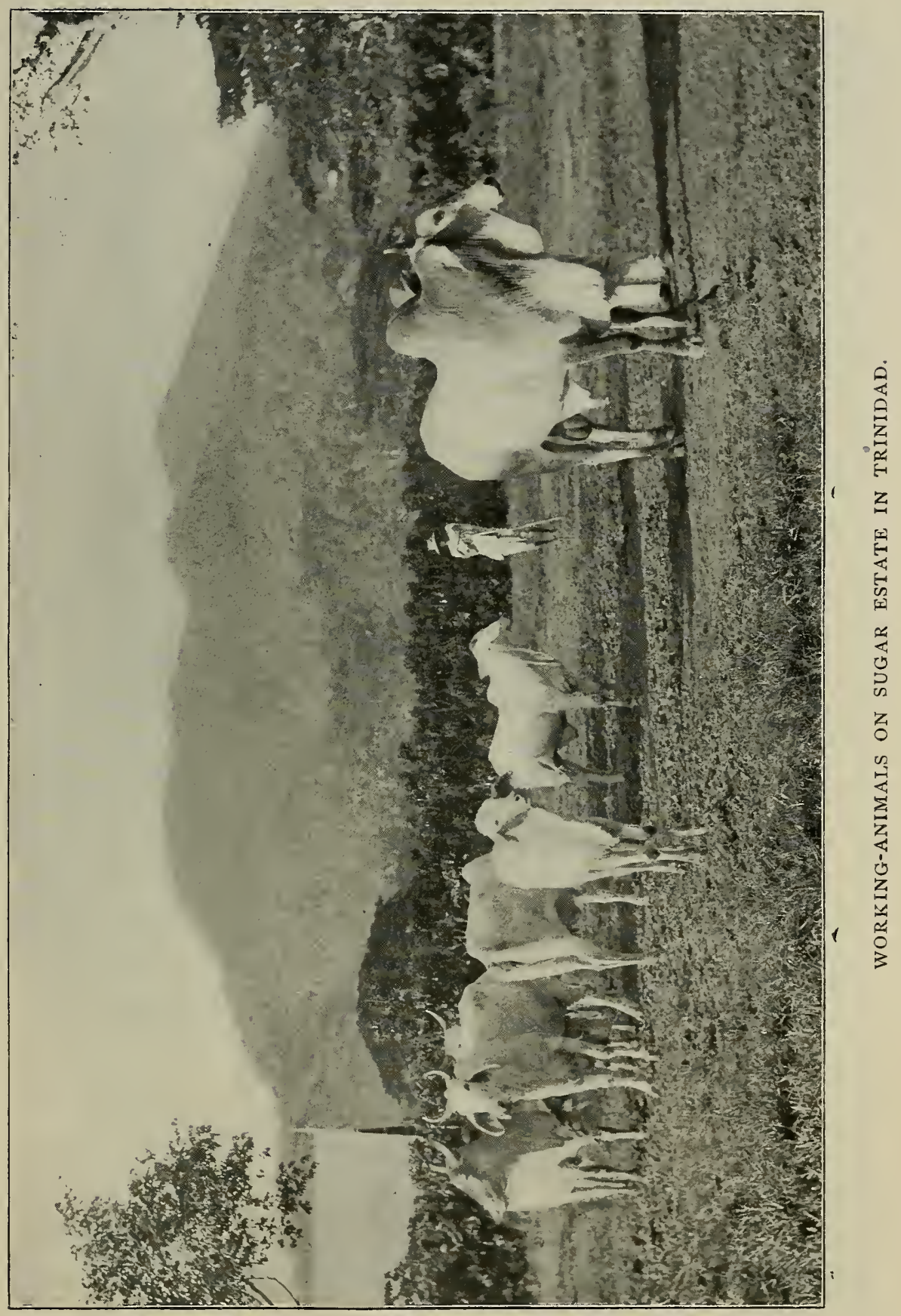




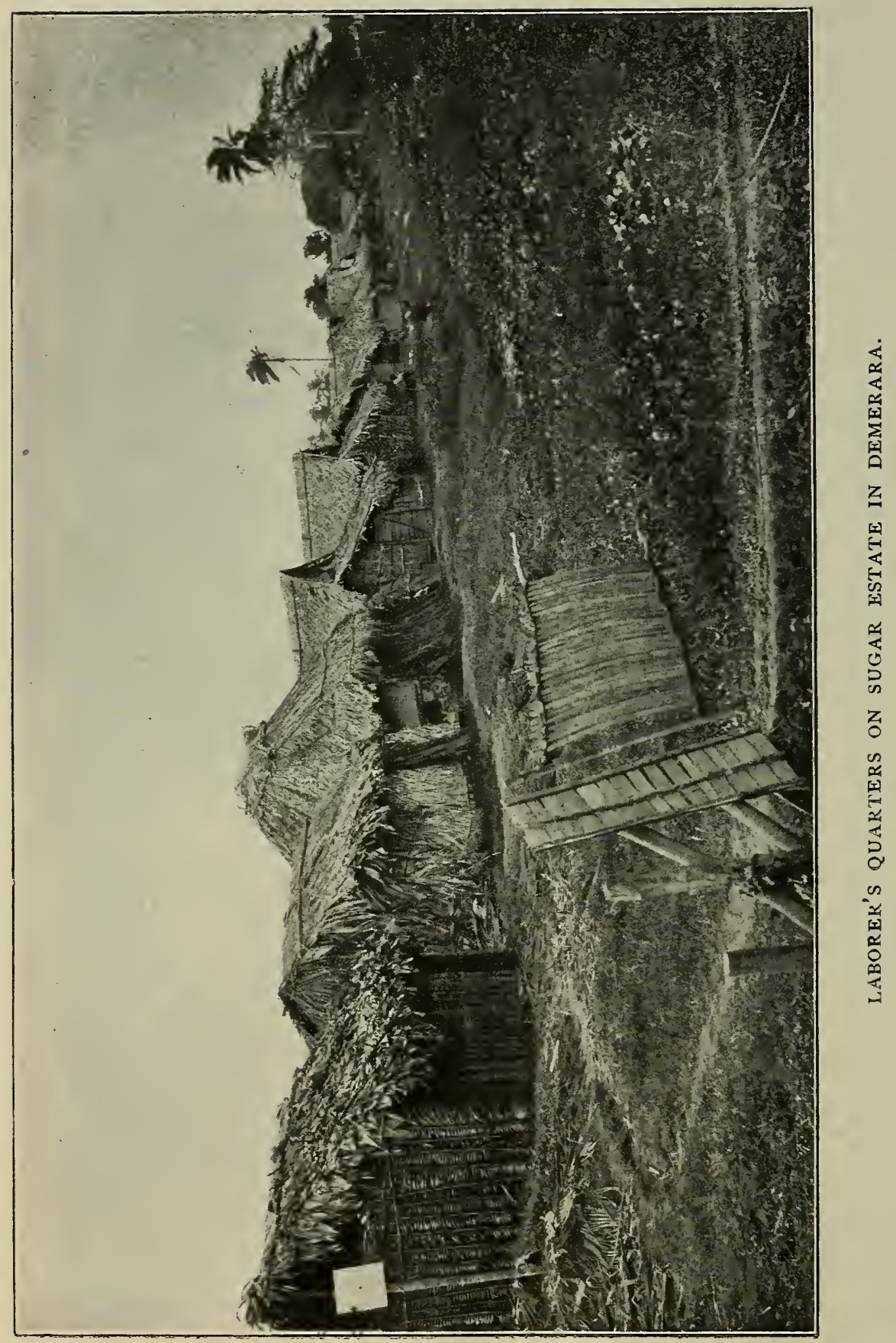


foliage matures. The stalk is nearer constant than the other parts of the cane, and even in it the amount of potash taken up, depending largely upon the variety and the soil growing it.

This consideration of the heavy draft of the plant food, especialy of potash and nitrogen, which a large cane crop makes on the soil, leads to study of the best way to keep up its fertility.

\section{FERTILIZING REQUIREMENTS OF CANE.}

Cane, like every other plant, needs for its growth a number of chemical substances, but, as most natural soils supply a large part of these ingredients in abundance, it is necessary here to consider only those which, in cultivated soils, are frequently more or less lacking. These are potash, phosphoric acid and nitrogen, and their relative relation to the cane crop has been the subject of important investigation and study at the Java Experiment Station. It was found that the absence of either of them was fatal to the life of the cane plant, and that, with an insufficient supply of any one of them, the plant grew slowly; but when all were present in ample quantities, it grew rapidly.

The skilled cane-grower ascertains what his soil requires in the way of potash, phosphoric acid or nitrogen, or all three of them, in order to produce strong, healthy plants, and then supplies that in which it is deficient. The object 
of the manufacturer of commercial fertilizers is to meet the exact needs of the planter, and so, while he sells each one of these separately, he also compounds them, by means of modern machinery, into what are styled "complete fertilizers," which are mixed and blended to suit the certain soils and the needs of the crop to be grown. Different forms of the same chemical may differ in action and effect, so form itself is to be considered in an economical administration of an estate. The following are the principal fertilizer ingredients and their sources.

Potash. The Stassfurt mines of Germany have placed within the reach of almost every civilized farmer and planter every useful form of potash, convenient to handle and cheap in price.

Sulphate of Potash is sold in two forms, one containing 50 per cent. and the other 27 per cent. potash. Sulphate is esteemed best for potatoes, tobacco and sugar cane, but both potash and sulphuric acid are plant foods, and cannot possibly injure the soil by their excessive use.

Muriate of Potash, containing 50\% or more of potash, is the most concentrated potash fertilizer in the market, is highly esteemed, and furnishes potash at the lowest price per pound. On soils deficient in lime, the sulphate is better than the muriate, since the muriate converts lime into a soluble chloride, which leaches out of the soil. For a similar reason soils already charged abundantly with common salt, are better served with the sulphate.

Kainit, a crude form of potash salt, contains on an 
average of 12.4 per cent. of pure potash. Besides potash, it contains chloride of sodium and magnesium. For sugar cane, concentrated potash, especially the sulphate, is to be preferred to the kainit.

Wood ashes formerly were our only commercial source of this important ingredient, but now they are rarely found on the market, and are so uncertain in strength that they cannot be recommended.

Phosphoric Acid is supplied to the planter in many forms; reference has already been made to bones, tankage and fish scrap. Mineral phosphates or rock phosphates are found abundantly in South Carolina, Florida and Tennessee and natural guanos on several of the "rainy" islands of the Caribbean Sea and Pacific Ocean. These guanos are the remains of the ordure of fish-eating birds, the nitrogen having been washed out by rains. All of these materials contain insoluble forms of phosphoric acid, and, in their natural state, have but little agricultural value; to be immediately available, on most soils, these raw phosphates must be treated with acid (generally sulphuric acid). This treatment converts them into acid phosphate or superphosphate, where the phosphoric acid is in a soluble (available) form, which is that most extensively used, and in the manufacture and sale of which millions of dollars of capital find profitable employment.

Peruvian Guano is also a natural or bird guano, coming from rainless countries, so that it still retains its nitrogen, and a part of its phosphoric acid, in available form. The 
deposits of Peruvian guano are now largely exhausted.

Another form of phosphoric acid, now offered, is a byproduct obtained in the manufacture of iron and steel from ores rich in phosphorus. The manufacturing process is known as the "Thomas Gilchrist patent," and this by-product is sometimes styled "Thomas Slag," as well as "Basic Slag." It contains about 44 per cent. of phosphoric acid, available to plants, though not as soluble as that contained in acid phosphate, and also, a large amount of caustic lime, on account of which it should not be mixed with fertilizers containing ammonia, because it would decompose such materials and release the volatile ammonia.

Nitrogen is supplied to the trade in many forms :

(I) Nitrate of Soda, a product of the mines of Chili. This form of nitrogen (nitrates) is that into which all others are resolved before they can serve as plant food. In whatever form it is supplied it must be rendered available by the work of microbes, acting in an areated, well drained soil, upon the nitrogenous matter present. Just here comes a suggestion, that many of the failures in applying organic forms of nitrogen to cane soils may be due to improper mechanical conditions, which prevent a rapid multiplication of microbes, and thereby retard the transformation into nitrates. This process of nitrification is an inherent concomitant of tilth, and soils in excellent tilth can consume and appropriate large quantities of organic nitrogen. Nitrate of soda readily leaches from a soil, especially an open, porous, sandy one, whenever not taken up by growing plants, 
and hence, to obtain its full effects, it should be applied to crops, at short intervals, in small quantities.

(2) Sulphate of Ammonia, a product of the distillation of coal and bones, is a by-product of the coal-gas factories of large cities. It contains a large percentage of nitrogen (22 per cent.) and is an excellent form for cane.

(3) Dried Blood, a product of slaughter houses, red or black in color, according to the method used in desiccation, contains from 12 to 18 per cent. nitrogen, and is esteemed as one of the best forms of organic nitrogen. It is largely used to supply the nitrogen in the compounding of cominercial fertilizers.

(4) Tankage, another refuse of slaughter houses, consists in the waste materials incident to preparing various meat products for market. Its composition is variable, and its availability as a fertilizer depends largely upon the character as well as composition of the materials of which it is composed. It contains a variable quantity of phosphoric acid, and is a favorite nitrogen fertilizer with the sugar planters of Louisiana.

(5) Fish Scrap, especially that obtained in large quantities from the Menhaden of the Atlantic coast, is used largely by manufacturers of commercial fertilizers as a source of nitrogen. The oil is extracted, and after that the steamed and dried residue, more or less finely ground, is sold as fertilizer, which, as it retains the meat and bones of the fish, like tankage, contains considerable phosphoric acid. 
(6) Bones, both raw and steamed, are extensively used for fertilizers, especially on soils filled with vegetable matter. They are usually finely ground, and their good results are frequently due more to the small percentage of nitrogen which they contain than to their large content of phosphoric acid, which, for the most part, is in an insoluble and unavailable form.

(7) Cottonseed Meal, gluten meal, linseed meal, castor pomace, sunflower cake, peanut cake, Chinese soja bean cake, rape seed cake, niger seed cake,-are all vegetable forms of nitrogen, obtained by extracting, under pressure, the oil from the various seeds and grinding the residue into powder. In Louisiana and other parts of the South, cottonseed meal, which contains about $7 \%$ nitrogen, $3 \%$ phosphoric acid and $2 \%$ potash, is extensively used as a fertilizer for cane, cotton, corn, etc.

\section{STABLE MANURES AND GREEN MANURING.}

Stable manure may be used on the cane crop with advantage, but its available amount is usually so small and insufficient, that it is of little practical importance to sugar planters. Where stable manure can be had, it is useful to the cane, especially for its nitrogen; but it is comparatively poor in potash and phosphoric acid, both of which must be supplemented in proper proportion if a full benefit be expected. 
Green manuring, that is, the raising of leguminous crops in rotation, like in other agricultural industries, is useful in sugar growing. Green manuring is regularly employed in Louisiana in a tri-ennial rotation of corn with cow-peas, plant cane and stubble cane. To this purpose the cow-pea is well adapted throughout the cane growing sections of the Atlantic and Gulf states, while in Barbados the Bengal Bean (Mucuna pruriens var.) has produced the best results, yielding a crop of 17,040 pounds per acre, containing $\mathrm{I} 20$ pounds of nitrogen. The indiscriminate growth of leguminous catch crops in Barbados is, however, not recommended, because of the evaporation of moisture from the great extent of leaf surface. Many soils there are underlaid, at a wepth of $1 \frac{1}{2}$ to $3 \frac{1}{2}$ feet, by a porous stratum of coral rock of great thickness, and so, with the capacity of the soil for storing water limited, if a leguminous crop be harvested late in the year, the young cane plant cannot find enough stored moisture to secure an early growth in the spring. Under such circumstances and conditions it is recommended that all such crops be grown early and cut not later than the middle of September, to give ample time for tillage and the accumulation of moisture near the surface. Local conditions must control action in this, as in every other precept of science, but, whenever existing conditions permit the growing of a strong, vigorous, leguminous catch crop, such action is strongly recommended.

The benefit derived from a rotation with legumes consists mainly in the large amount of nitrogen which these 
crops gather from the air and furnish to the succeeding cane crop through their decaying stalks and leaves. A crop of cow-peas (dry) of $4500 \mathrm{lbs}$. per acre will contain approximately $65 \mathrm{lbs}$. of nitrogen, mostly gathered from the air, without cost to the grower, and corresponding to 420 lbs. of nitrate of soda.

It must be kept in mind that these legumes, greedy feeders as they are on the nitrogen of the air, need considerable amounts of phosphoric acid and potash, both of which need to be supplied to the soil so that a heavy crop of legumes may be produced and a correspondingly large amount of nitrogen acquired free of cost. An application of $300 \mathrm{lbs}$. of acid phosphate, and Ioo lbs. of muriate of potash per acre is advisable for cow-peas and other legumes.

\section{FERTILIZER REQUIREMENTS OF CANE SOILS.}

By the chemical analysis of a crop, we can learn the quantities of potash, phosphoric acid and nitrogen required to produce it. It has already been stated in the preceding pages that growing sugar cane needs very large quantities of potash and nitrogen, and smaller amounts of phosphoric acid.

If the cane growing soil were without plant food, all of which must be artificially applied, the question of manuring 
would be one of simple calculation of the amounts of fertilizer ingredients contained in the crop;-but there is already present in the soil a certain amount of such food available to the plant, with no need of supplying it artificially. Every ambitious, scientific, practical sugar planter asks himself the following questions :

I. What quantities of phosphoric acid, potash and nitrogen do my soils need for the production of good yields?

2. In what forms shall I supply the fertilizing elements?

A chemical analysis of a soil discloses the quantities of each plant food ingredient present in it, but as the larger part of its potash, phosphoric acid and nitrogen exists in an insoluble, unavailable form, it is far more important to learn what and how much is availably present. Unfortunately chemical science has not yet succeeded in finding a method whereby the available can be distinguished from the nonavailable plant food contained in a soil. Some such methods were designed and are now used by some chemists, but it is the prevailing opinion of scientists that accurate and reliable information is not conveyed thereby, and that its nearest approach is reached through the indirect way of socalled field or fertilizer experiments. Such judiciously planned and carefully conducted experiments have been made in many cane-growing countries, and valuable inform. ation obtained and conclusions drawn from them. The following is a summarizing and general review of such observations in the several countries: 
In Hawaii, which practices the heaviest fertilizing and secures the largest yield of sugar per acre, the greatest variation and widest range in soil, rainfall, irrigation and cultivation is found. Mr. Chas. F. Eckart, the present director of the Hawaiian Experiment Station, makes the following report as to the fertilizers successfully used on the four cane growing islands.

Oahu, 8.50 to 14.60 per cent. potash, in the form of sulphate of potash, 7 to 15 per cent. available phosphoric acid, and 4.7 to 7.1 per cent. nitrogen, in three forms, - nitrate of soda, sulphate of ammonia, and organic material.

Maui, 4.13 to 17.34 per cent. potash, 5.7 to 14.26 per cent. phosphoric acid, and 5.5 to 9.7 per cent. nitrogen.

Kauai, 4.89 to IO.I per cent. potash, 5.68 to 9.39 per cent. phosphoric acid, and 6.06 to 9.9 I per cent. nitrogen.

Hawaii, 4.03 to 22.54 per cent. potash, 5.29 to 14.6 I per cent. phosphoric acid, and 3.25 to 10.42 per cent. nitrogen. This island possesses a diversity of conditions, to each of which it conforms in applying mineral fertilizer. Where heavy rainfalls prevail, organic nitrogen washes out less, and is preferred; and no nitrate of soda and little sulphate of ammonia is used. In the Hamakua district, the nitrogen is in the form of sulphate of ammonia, the phosphoric acid as acid phosphate, and potash as sulphate of potash.

Experiments in Honolulu with plant cane and first year rattoons gave, per acre, from different combinations of fertilizers : 


\section{Results of Experiments on Plant Cane harvested in 1899.}

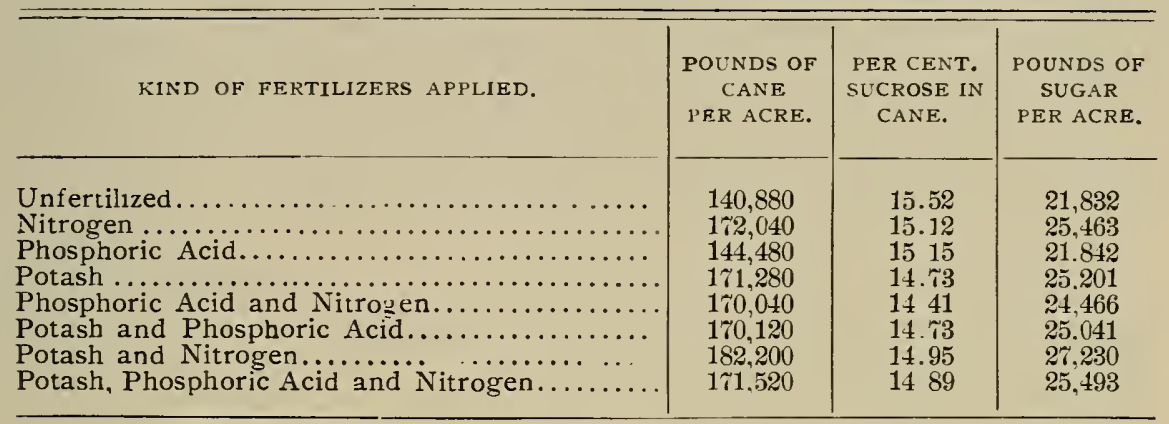

\section{Results of Experiments on Rattoons harvested in 1900.}

\begin{tabular}{|c|c|c|c|}
\hline KIND OF FERTILIZERS APPLIED. & $\begin{array}{l}\text { POUNDS OF } \\
\text { CANE } \\
\text { PER ACRE }\end{array}$ & $\begin{array}{l}\text { PER CENT. } \\
\text { SUCROSE } 1 \text { N } \\
\text { CANE. }\end{array}$ & $\begin{array}{l}\text { POUNDS OF } \\
\text { SUGAR } \\
\text { PER ACRE. }\end{array}$ \\
\hline 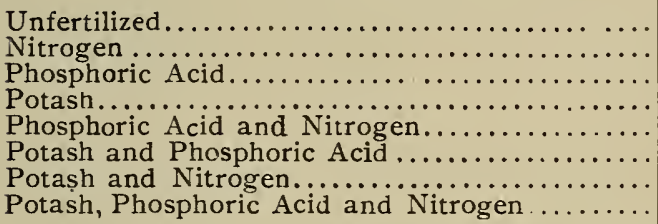 & $\begin{array}{l}126,424 \\
174636 \\
144.715 \\
151,780 \\
210,161 \\
153,065 \\
222,134 \\
221,297\end{array}$ & $\begin{array}{l}16.65 \\
14.10 \\
15.65 \\
15.81 \\
13.53 \\
14.55 \\
13.85 \\
13.20\end{array}$ & $\begin{array}{l}21086 \\
24,631 \\
22,639 \\
23,985 \\
28,463 \\
22,272 \\
31,008 \\
29,265\end{array}$ \\
\hline Average.. & 175,526 & 14.68 & 25,419 \\
\hline
\end{tabular}

The fertilizer applied in the rattoon experiment furnished I 82 pounds nitrogen, 255 pounds actual potash, and I $_{4} 8$ pounds phosphoric acid, equivalent to 920 pounds sulphate of ammonia or II 37 pounds nitrate of soda, 5 Io pounds sulphate of potash, and rooo pounds acid phosphate. The most profitable combination was nitrogen and potash, which produced an increase of 9,922 pounds of sugar over the unfertilized plot. 
In Louisiana, cane is grown only on the alluvial soil, and its Sugar Experiment Station has concluded that a fertilizer, rich in nitrogen with a small quantity of available phosphoric acid, is best suited to it. The proportion of nitrogen is increased on rattoons and succession plant cane.

Throughout the Georgia and Florida coast region, mixtures of cottonseed meal, acid phosphate and kainit are almost exclusively used, and produce good results.

Barbados finds nitrogen, preferably nitrate of soda and sulphate of ammonia, most effective; phosphoric acid in acid phosphates is beneficial when used in moderation, but diminishes the yield when applied in excessive quantities

Demerara derives the most benefit from nitrogen as sulphate of ammonia, with Thomas slag, the most effective source of phosphoric acid.

The Leeward Islands have, apparently, no great demand for nitrogen, although on soils not recently treated with pen manure, its results are marked. Phosphates do not increase their cane yield, but in many instances decrease it, while potash with nitrogen gives their largest yields.

In a publication of the Imperial Department of Agriculture for the West Indies, Francis Watts shows that on land where pen manure had not been previously used, an application of 60 pounds potash ( $120 \mathrm{lbs}$. sulphate of potash) per acre produced an increase of 393 pounds of sugar, and of 2318 pounds of sugar, when nitrugen and phosphoric acid were added to the potash. 
Upper Egypt secures the best results from a complete fertilizer containing potash, phosphoric acid and nitrogen, as shown by an increase of 2659 pounds sugar per acre in I 900 in experiments conducted by Prof.W. Tiemann, Director of the Agricultural Experiment Station, Cheik Fadl. His tabulation is :

\begin{tabular}{|c|c|c|c|c|}
\hline $\begin{array}{l}\text { PLOT } \\
\text { NO. }\end{array}$ & POUNDS FERTILIZER PER ACRE, & $\begin{array}{c}\text { POUNDS } \\
\text { SUGAR CANE } \\
\text { PER ACRE. }\end{array}$ & $\begin{array}{l}\text { PER CENT. } \\
\text { SUGAR } \\
\text { IN THE } \\
\text { CANE. }\end{array}$ & $\begin{array}{l}\text { POUNDS } \\
\text { SUGAR } \\
\text { PER ACRE. }\end{array}$ \\
\hline $\begin{array}{l}1 . \\
2 . \\
3 . \\
4 . \\
5 . \\
6 . \\
7 . \\
8 .\end{array}$ & 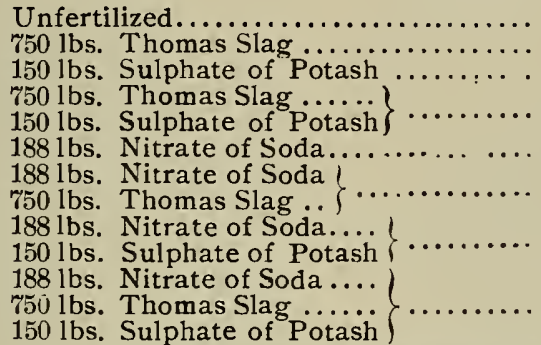 & $\begin{array}{l}43,494 \\
49006 \\
47,508 \\
53,: 01 \\
55,661 \\
56,285 \\
53,582 \\
59,157\end{array}$ & $\begin{array}{l}13.2 \\
14.0 \\
13.8 \\
13.8 \\
13.0 \\
13.9 \\
13.7 \\
14.2\end{array}$ & $\begin{array}{l}5741 \\
6861 \\
6,556 \\
7,328 \\
7,236 \\
7,824 \\
7,341 \\
8,400\end{array}$ \\
\hline
\end{tabular}

For cane, where fertilizer requirements have not been ascertained by practical experiments, the safest and best plan is to use that which contains a liberal amount of potash, a moderate amount of phosphoric acid and an excess of nitrogen.

- The best forms of plant food, for average conditions, are:-for potash, high grade sulphate of potash; for nitrogen, nitrate of soda and sulphate of ammonia; and for phosphoric acid, acid phosphate, or, on some soils, Thomas slag is preferable. 


\section{QUANTITY OF FERTILIZERS PER ACRE, AND HOW TO APPLY THEM.}

The Hawaiians frequently use a ton (2000 lbs.), or more, of fertilizer per acre, applying it at two different times, first at planting, or soon after the cane is well up, and a second time at the opening of the following spring. Mr. Pogue of Kihei Plantation has successfully applied nitrate of soda in the irrigation waters; as a question of economy, it is proposed to apply all soluble fertilizers in this manner.

In Louisiana the amount of fertilizer used is 400 to 700 lbs. per acre. Nitrogen in excess of 48 lbs. per acre, which is about the limit of assimilation in an average season, has been found by the Experiment Station to be wasteful, and phosphoric acid at the rate of $36 \mathrm{lbs}$. ample. Fertilizers are usually applied at the time of planting or at the time of throwing the first soil to the young cane, whether plant or stubble, by manure distributing machines constructed to scatter the fertilizer on both sides of the row at the same time.

In Barbados 40 to $80 \mathrm{lbs}$. of nitrogen, preferably as $2 / 3$ sulphate of ammonia and $\mathrm{I} / 3$ nitrate of soda, per acre is correct; a small part applied shortly after the cane germinates and the remainder in June and August, when the cane's growth is most rapid, together with 80 to roo lbs. of sulphate of potash. Phosphates are not especially recom- 


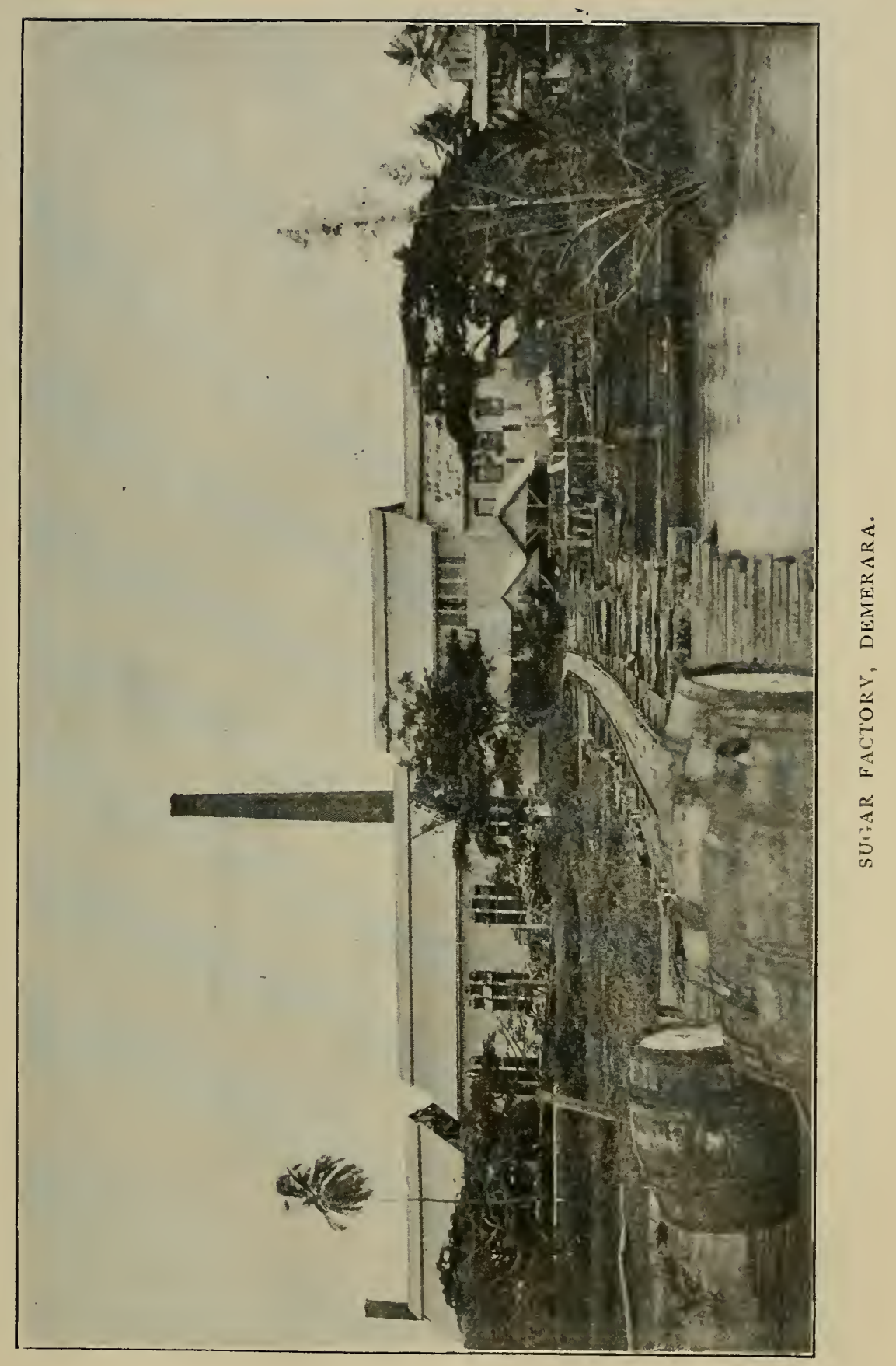




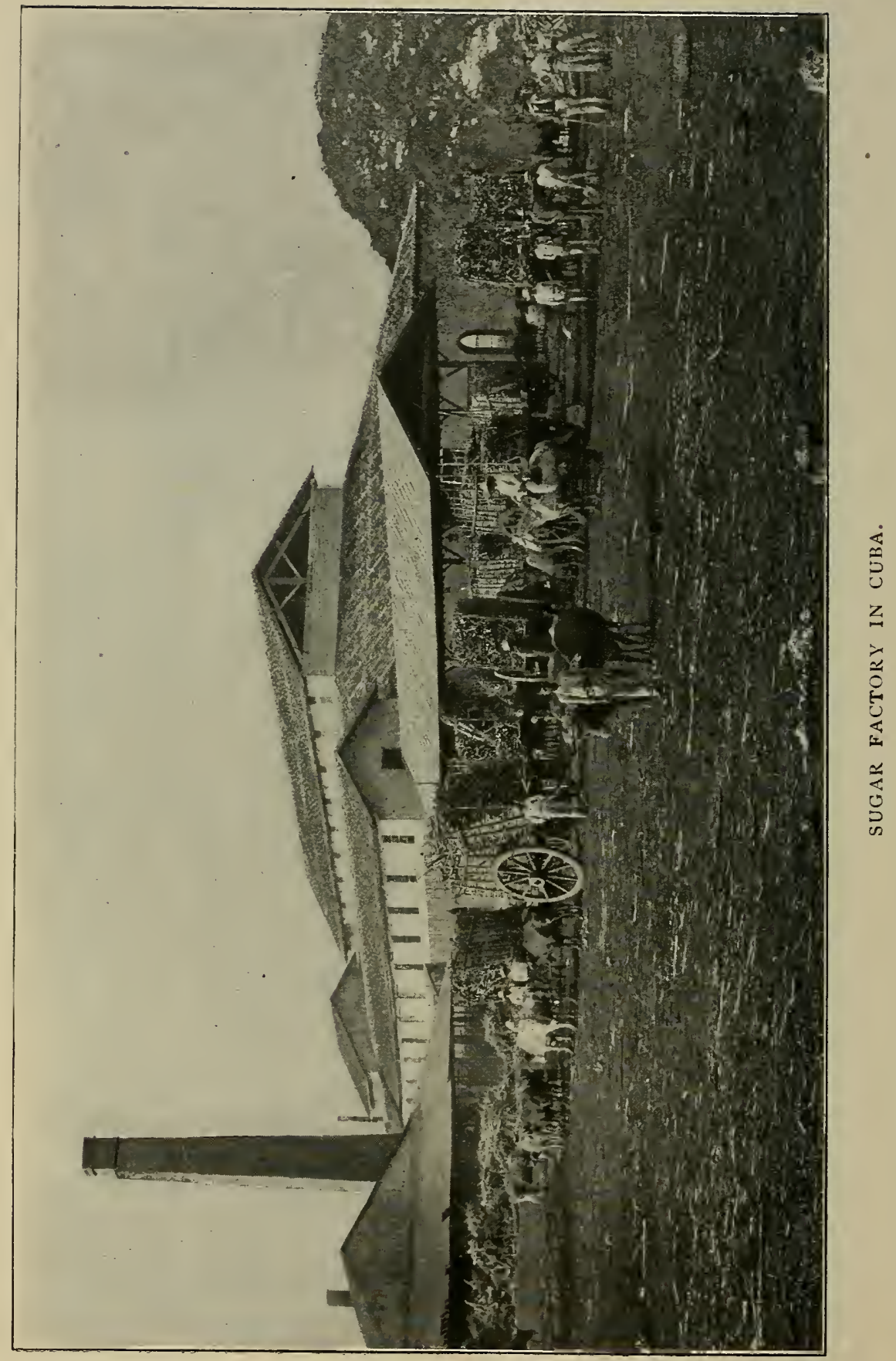


mended, but, when used, should contain from 30 lbs. (on rattoons) to $40 \mathrm{lbs}$. (on plant cane) of phosphoric acid per acre.

For Demerara's stiff clay, 50 lbs. of nitrogen, in the form of sulphate of ammonia, with 500 to $600 \mathrm{lbs}$. finely ground slag phosphate per acre is considered about right by Prof. Harrison. Both are applied to plant cane at an early period and in one dressing, but sufficient s'ag phosphate remains in the soil to supply the rattoons.

\section{VALUE OF FERTILIZERS.}

Generally speaking, the question of profit or loss in cane growing turns on the intelligent selection of fertilizer, the correct use of which frequently doubles a yield.

The high esteem in which fertilizers are held by the Hawaiian sugar growers may be inferred from the large quantity used annually. Director Eckart asserts that in 190I, "no less than twenty-five thousand tons of commercial fertilizers" were added to the Hawaiian soils to satisfy the demand of the sugar industry. The shrewd business wisdom of this enormous consumption is made plain by the statement of Dr. Maxwell, that where the trash of the cane is returned to the soil, each ton of sugar produced removes from the soil in cane 12.7 lbs. nitrogen, 35.3 lbs. potash, and 8.2 lbs. phosphoric acid. With the total sugar yield of the islands approaching 300,000 tons, on about 50,000 acres 
of land, the demand for this large quantity of fertilizers is apparent.

The secret of a profitable sugar industry lies in economically growing robust cane, rich in sugar; and no soil is so rich as to continue year after year to grow large and remunerative crops, unless the plant food removed by the crop be returned in the form of fertilizers. Those sugar countries, which are growing the largest crops of cane per acre, are the most prosperous. A careful study of their practices teaches that they obtain success and wealth by thorough preparation of the soil, judicious fertilizing, intelligent cultivation (including irrigation when required), and an elimination of rattoons as soon as their yields drop below a profit-producing quantity.

The world's experience is that no one crop can be grown continuously and profitably on the same unfertilized soil, no matter how rich it was at the beginning. Sugar cane is a most exacting as well as soil exhausting crop. In a report recently made to the Queensland Government upon the condition of the sugar industry of Australia, Dr. Walter Maxwell, Director of the Sugar Experiment Stations at Brisbane, emphasizes the necessity of feeding and so restoring to those soils their former fertility, which, according to Hon. W. H. Groom, had fallen in annual yield from 40 tons of cane in the beginning to 16,13 and 12 tons, in 1889 , and according to the report, for 1900 in North Mackay, to from 4 to 5 tons, and, in other districts, to from 7 to 8 tons. Dr. Maxwell says: "The average yield of cane 
to-day througnout Queensland is about I5 tons per acre, as against about 46 tons per acre during the earlier years of the industry." Further on, after showing by analyses of virgin soils and those continually cropped with cane, a loss of $3 \mathrm{r} \%$ nitrogen, $42.2 \%$ potash, and $37.2 \%$ lime in the latter, he adds: "Their immediate yielding power has been seriously impaired, but by more modern methods of cultivation, rendering available the reserve stores of plant food and by returning to the lands those elements which have been and are being removed, the producing power can be restored." Intelligent cultivation, and a judicious use of fertilizers can, without a doubt, restore the original producing power to these soils, and obtain 40 tons of cane per acre. More than that, here as elsewhere, by the application of scientific resources and intelligence, better and larger crops can be grown than those first produced by the "virgin soil."

Modern methods of farming and planting recognize the value of fertilizers for every soil and every crop, and the sugar planter, alive to the advantages of the present age, knows well that cane culture is among the most intense agricultural industries, where the size and profit of his crop is largely determined by the intelligent use of heavy applications of fertilizer. 


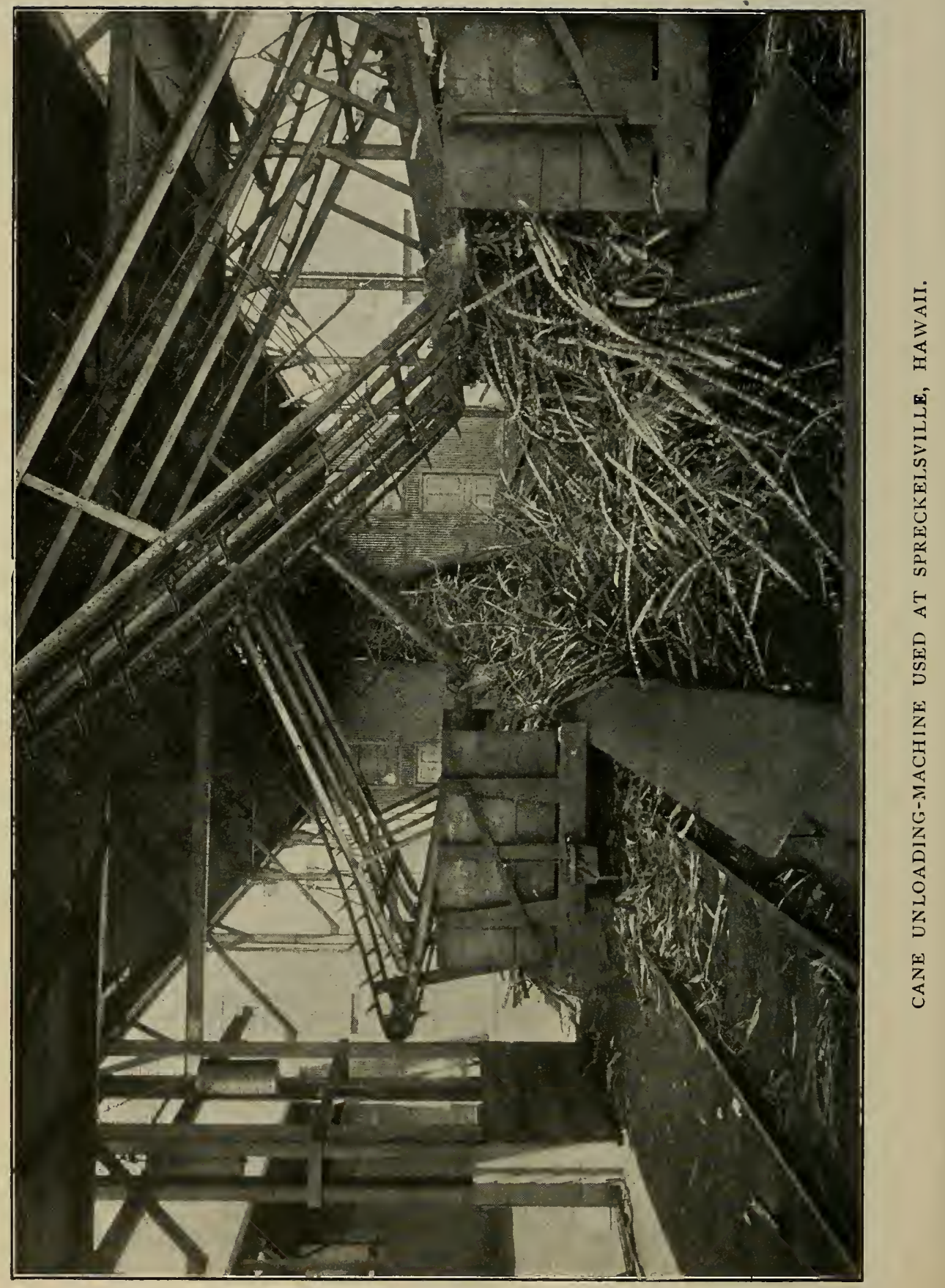




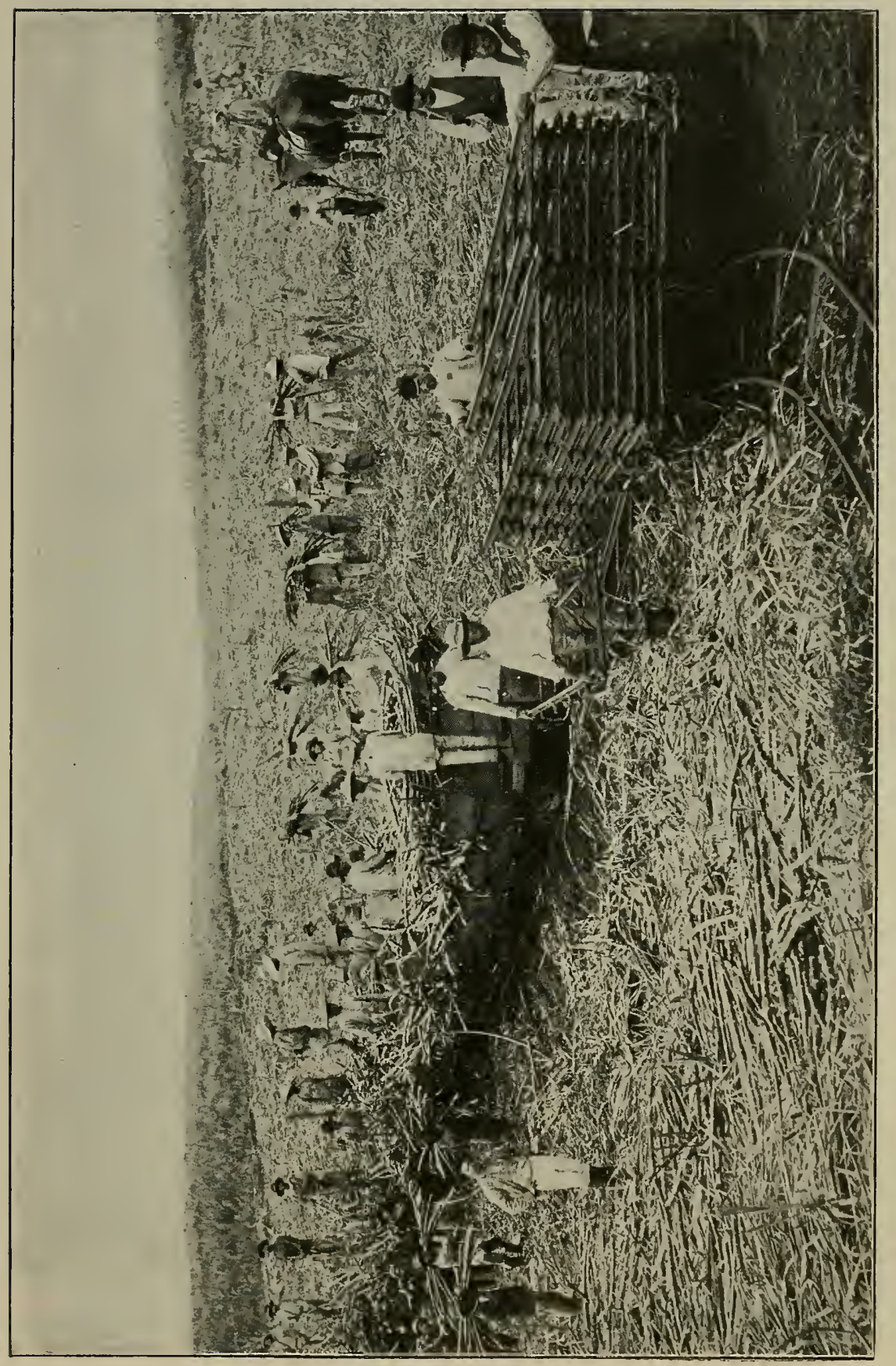

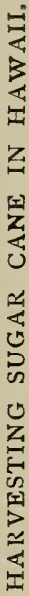




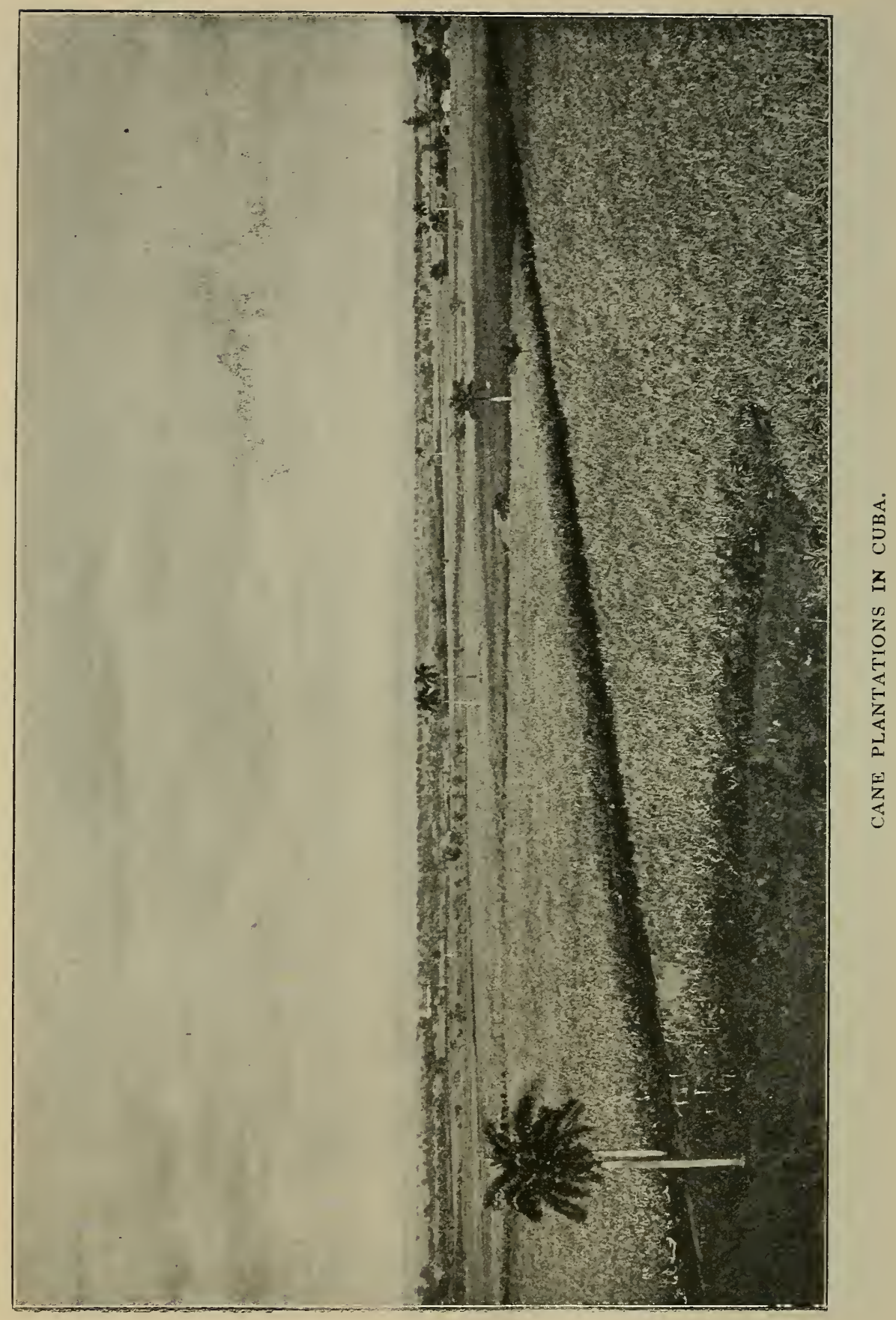


Composition of Fertilizer Materials Used as Sources of Potash.

Muriate of Potash..... Sulphate of Potash (high grade)........ Sulphate of Potash Magnesia...........

Kainit...............

Sylvinit .................

Cotton - Seed - Hull Ashes.

Wood - Ashes ;

(unleached) $\} \cdots . .$.

Wood-Ashes (leached).

Tobacco-Stems .......

\begin{tabular}{|c|c|c|c|c|c|}
\hline $\begin{array}{c}\text { Pure } \\
\text { Potash } \\
\left(\mathrm{K}_{2} \mathrm{O}\right) \\
\text { PerCt. }\end{array}$ & $\begin{array}{l}\text { Lime } \\
\text { Per Ct. }\end{array}$ & $\begin{array}{l}\text { Nitro- } \\
\text { gen } \\
\text { Per Ct. }\end{array}$ & $\begin{array}{c}\text { Ammonia } \\
\text { Per Ct. }\end{array}$ & $\begin{array}{l}\text { Phos- } \\
\text { phoric } \\
\text { Acid, } \\
\text { Total, } \\
\text { Per Cent }\end{array}$ & $\begin{array}{l}\text { Chlorine } \\
\text { Per Cent. }\end{array}$ \\
\hline 50 & & & & & 45 to 48 \\
\hline 5oto 55 & & & & & 0.3 " 1.5 \\
\hline $27 " 30$ & 0.85 & & 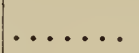 & & I. 5 “" 2.5 \\
\hline $\begin{array}{r}12 \frac{1}{2} \\
16 \cdot 20\end{array}$ & I. I 2 & & & & $\begin{array}{l}30 \text { to } 32 \\
42 \text { " } 46\end{array}$ \\
\hline 20 & & $\ldots$ & .. & $\ldots \ldots$ & $\begin{array}{ll}42 & 40 \\
\ldots \ldots\end{array}$ \\
\hline $20 " 30$ & & I3tor 4 & I6 to I 7 & & \\
\hline $2 " * 8$ & $30 t 055$ & & & I to 2 & \\
\hline$I " 2$ & 35 “" 40 & & & I to $I_{\frac{1}{2}}$ & \\
\hline 5 " 8 & 3.5 & 2 to 3 & $2 \frac{1}{2}$ to $3 \frac{1}{2}$ & & $\ldots \ldots$ \\
\hline
\end{tabular}

\section{Average Composition of the Most Important}

Farm Manures.

\begin{tabular}{|c|c|c|c|c|c|}
\hline \multirow[t]{2}{*}{ FARM MANURES. } & \multirow[t]{2}{*}{ Nitrogen. } & \multirow{2}{*}{$\begin{array}{c}\text { Equivalent } \\
\text { in } \\
\text { Ammonia. }\end{array}$} & \multirow{2}{*}{$\begin{array}{l}\text { Potash } \\
\left(\mathrm{K}_{2} \mathrm{O}\right) .\end{array}$} & \multicolumn{2}{|c|}{$\begin{array}{c}\text { Phosphoric Acid } \\
\left(\mathrm{P}_{2} \mathrm{O}_{5}\right) .\end{array}$} \\
\hline & & & & Total. & Lime $(\mathrm{CaO})$. \\
\hline Cow-Manure (fresh) & 0.34 & $0.4 \mathrm{I}$ & 0.40 & 0.16 & $0.3 \mathrm{I}$ \\
\hline Horse-Manure (fresh). & $0.5^{8}$ & 0.70 & 0.53 & 0.28 & $0.2 \mathrm{I}$ \\
\hline Sheep-Manure (fresh). & 0.83 & 1.00 & 0.67 & 0.23 & 0.33 \\
\hline Hog-Manure (fresh) & 0.45 & 0.54 & 0.60 & 0.19 & 0.08 \\
\hline Hen-Dung (fresh). & 1.63 & I. 98 & 0.85 & I. 54 & 0.24 \\
\hline Mixed Stable Manur & 0.50 & 0.60 & 0.63 & 0.26 & 0.70 \\
\hline
\end{tabular}




\section{Composition of Fertilizer Materials Used}

\section{as Sources of Nitrogen.}

\begin{tabular}{|c|c|c|c|c|}
\hline & Nitrogen. & $\begin{array}{c}\text { Equivalent } \\
\text { in } \\
\text { Ammonia. }\end{array}$ & $\begin{array}{l}\text { Potash } \\
\left(\mathrm{K}_{2} \mathrm{O}\right) .\end{array}$ & $\begin{array}{c}\text { PhosphoricAcj } 3 \\
\text { Total. }\end{array}$ \\
\hline Nitrate of Soda. & I 5 to 16 & I 8 to $19 \frac{1}{2}$ & & $\ldots$ \\
\hline Sulphate of Ammonia... & 19 " 22 & 23 “ 26 & $\ldots$ & \\
\hline Dried-Blood (high grade)... & 12 " $12 ?$ & $I 4 \frac{1}{2}$ “ $I 7 \frac{1}{2}$ & $\ldots \ldots$ & $\ldots \ldots \ldots$ \\
\hline Dried-Blood (low grade) ... & IO “II & I 2 “ ' $4 \frac{1}{2}$ & & 3 to 5 \\
\hline Concentrated Tankage..... & I I “ $14 \frac{1}{2}$ & I $3 \frac{1}{2}$ “ I 5 & $\ldots$ & I $\quad$ " 2 \\
\hline Tankage............. & $5 " 6$ & $6 \cdot 7 \frac{1}{2}$ & $\ldots \ldots$ & I I $\quad$ “ I 4 \\
\hline Tankage.......... & $7 \frac{1}{2} * 9$ & 9 “ I I & & $8 \frac{1}{2} “ 10 \frac{1}{2}$ \\
\hline Dried Fish-Scrap .... & $9 \frac{1}{2}$ “ I I & I I $\frac{1}{2}$ “ “ I $3 \frac{1}{2}$ & .. & 6 6 8 \\
\hline Cotton-Seed Meal .. & $6 \frac{1}{2} ، 7 \frac{1}{2}$ & $8 ، 9$ & $\mathrm{I} \frac{1}{2} \%$ & $2 \%$ \\
\hline Castor Pomace......... & $5 ، 6$ & $6 ، 7 \frac{1}{2}$ & I $\%$ & $2 \%$ \\
\hline Tobacco Stems..... & $2 “ 3$ & $2 \frac{1}{2} " 4$ & 5 to 8 & about $\mathrm{s} \%$ \\
\hline
\end{tabular}

\section{Composition of Fertilizer Materials Used}

\section{as Sources of Phosphoric Acid.}

\begin{tabular}{|c|c|c|c|c|c|c|}
\hline & \multirow{2}{*}{$\begin{array}{l}\text { Nitro- } \\
\text { gen. }\end{array}$} & \multirow{2}{*}{$\begin{array}{c}\text { Equiv- } \\
\text { alent in } \\
\text { Ammo } \\
\text { nia. }\end{array}$} & \multirow{2}{*}{$\begin{array}{c}\text { Potash } \\
\left(\mathrm{K}_{2} \mathrm{O}\right)\end{array}$} & \multicolumn{3}{|c|}{ Phosphoric Acid. } \\
\hline & & & & Total. & A vailable. & Insoluble. \\
\hline $\begin{array}{l}\text { So Carol'a Phos. Rock } \\
\text { So. Carolina A c id } \\
\text { Phosphate...... } \\
\text { Florida Land Rock.. } \\
\text { Florida Pebble Phos- } \\
\text { phate.......... } \\
\text { Florida Acid Phos- } \\
\text { phate........... } \\
\text { Tennessee Phosphate } \\
\text { Tennessee Acid Phos- } \\
\text { phate. .......... } \\
\text { Bone-Black (spent). } \\
\text { Bone-Black(dissolved) } \\
\text { Bone-Meal. ......... } \\
\text { Bone (dissolved) ..... } \\
\text { Peruvian Guano ..... }\end{array}$ & $\begin{cases}\cdots & \cdots \\
\cdots & \cdots \\
2 \frac{1}{2} \text { to } 4 \frac{1}{2} \\
2 & \text { “ } 3 \\
6 & \text { “I }\end{cases}$ & {$\left[\begin{array}{lll}\cdots & \cdots & \cdots \\
\cdots & \cdots & \cdots \\
3 & \text { to } & 5 \frac{1}{2} \\
2 \frac{1}{2} & \text { “ } & 3 \frac{1}{2} \\
7 \frac{1}{4} & \cdots & \end{array}\right.$} & $\begin{array}{l}\ldots \ldots \\
\cdots \\
\cdots \\
\cdots \\
\cdots \\
\cdots \\
\cdots \\
\cdots \\
1 \frac{1}{2} \text { to } 4\end{array}$ & 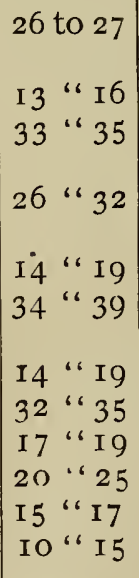 & 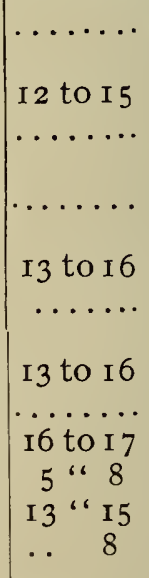 & 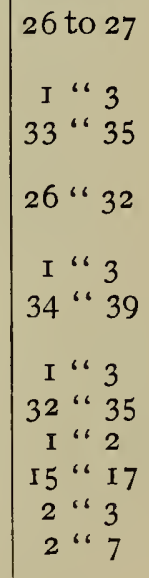 \\
\hline
\end{tabular}





